\title{
THE VARIATION OF CEPAEA NEMORALIS IN THREE PYRENEAN VALLEYS
}

\author{
R. A. D. CAMERON, M. A. CARTER and F. N. HAYNES \\ Department of Biological Sciences, Partsmouth Polytechnic, Portsmouth, Hants.
}

Received 16.viii.72

\section{SUMMARY}

Samples ofCepaea nemoralis $(\mathrm{L})$ have been made in three Pyrenean valleys to study factors influencing variation in the shell colour and banding polymorphism. Botanical evidence has been used to draw conclusions about the climate and habitat of each site.

In the Jueu valley, north of the Pyrenean watershed (sampled from 750 to $1900 \mathrm{~m}$. a.sl.), morph frequencies of $C$. nemoralis vary in such a way as to suggest the operation of climatic selection. The frequencies of yellow and unbanded shells increase with altitude, and are at or near fixation in all populations subject to sub-alpine climatic conditions (over $1450 \mathrm{~m}$.). Frequencies of white-lipped shells vary with altitude in a more complex way, banded whitelipped shells being frequent at the base of the valley, and unbanded ones at the head; all white-lipped shells are rare in the intermediate altitudes. Woodland samples in the Jueu have higher frequencies of pink and unbanded shells than those from open habitats at comparable altitudes, suggesting the operation of visual selection for crypsis.

In the valley of the Noguera Ribagorzana, south of the watershed (sampled from 750 to $1760 \mathrm{~m}$.), there are also altitudinal and habitat influences on morph frequencies. Pink and banded shells occur at high frequencies only in the montane zone (above $1300 \mathrm{~m}$.) while in the Mediterranean zone (750$900 \mathrm{~m}$.) there are very high frequencies of yellow and effectively unbanded shells. Between these extremes there is variation at the colour locus with habitat, brown shells occurring at high frequencies in the denser and more shaded habitats.

The third valley sampled, that of the Noguera de Tort, joins the Noguera Ribagorzana, and contains a similar range of habitats and vegetation zones, but does not show the same pattern of variation in morph frequencies. There is some variation with altitude, but the pattern is not nearly as clear as in the other two valleys.

In spite of the evidence that climatic selection is acting on $C$. nemoralis populations in the Pyrenees, there is little consistency in morph frequencies between populations from the same vegetation zone in different valleys. It is suggested that consideration of variations in climate within zones and of the past history of the populations is necessary to account for the variation observed.

\section{IntRoduction}

THE shell colour and banding polymorphism of the snail Cepaea nemoralis (L) has been extensively investigated, and factors affecting it have been described. Visual selection by predators influences morph frequencies in several areas (Cain and Sheppard, 1954; Currey, Arnold and Carter, 1964; Carter, 1968. Selective agents, as yet undetermined, act to produce "Area effects" in other districts (Cain and Currey, 1963; Carter, 1968). Variations in morph frequencies with climate have been found both in broad geographical surveys in France (Lamotte, 1966) and in detailed studies of 
smaller areas, in Brittany (Guerrucci-Henrion, 1966), in the Pyrenees (Arnold, 1968, 1969; Lamotte, 1968 $a, b$ ) and in western Ireland (Cameron, 1969). Differential survival and fertility of morphs subjected to various temperature regimes in the laboratory show that climate can act as a selective agent (Lamotte, 1966; Wolda, 1967).

The work of Arnold $(1968,1969)$ on $C$. nemoralis in high Pyrenean valleys shows, with particular clarity, that changes in morph frequencies there are associated with change in altitude, aspect and topography. These changes are ascribed to the action of climatic selection. This paper reports on work carried out to confirm and expand that of Arnold, by increasing the number of valleys sampled and by attempting to define the kinds of climatic regimes in which particular morph frequencies occur.

The most difficult problem in such a study lies in obtaining accurate and relevant climatological data. The variations in microclimate produced by changes in vegetation, aspect and shelter (Geiger, 1959) make most meteorological data useless for this purpose, but for the large number of sites investigated it is impossible to make meaningful microclimatic measurements at each. In order to overcome this problem we have classified our samples as to climate in an indirect way, by using the extensive body of information on the variation in distributions of plant species and communities with climate and altitude.

\section{ThE areas STUDIED}

Fig. 1 shows the position of our study areas. The Jueu is a tributary of the Garonne, and is part of the Valle de Aran sampled by Arnold (1968), who took only five samples from the Jueu valley itself. The valleys of the Noguera Ribagorzana and the Noguera de Tort start immediatelysouth of the Valle de Aran, on the other side of the watershed.

\section{(i) The fueu valley (fig. 2)}

The Valle de Aran, carrying the headwaters of the Garonne, is a Spanish enclave to the north of the Pyrenean watershed. Arnold (1968) gives a general description of the valley, and there are detailed accounts of the geology in Kleinsmiede (1960) and of vegetation and climate in Rijckborst (1967).

The Jueu valley is wide and flat-bottomed at its mouth, which is climatically and botanically similar to the main valley, being somewhat drier than the rest, with mixed deciduous woods dominated by Quercus pubescens, albeit showing signs of human disturbance.

Above this area the sides close in, and the valley is narrow bottomed for most of its length. The middle section of the valley has heavily wooded sides, with beech Fagus sylvatica or mixed beech and fir Abies alba stands predominating. The valley bottom is partly cleared, but agricultural activity has declined, and the degree of abandonment increases away from the village at the mouth. Small patches of alluvial flats and gentle slopes are still maintained as meadows.

At the Guells de Jueu the valley becomes much steeper and the woods of the slopes join across the valley bottom. Above this, the valley splits into two wide-bottomed cirques separated by a wooded ridge. The sides of both are wooded, but the bottoms are heavily grazed pastures. 


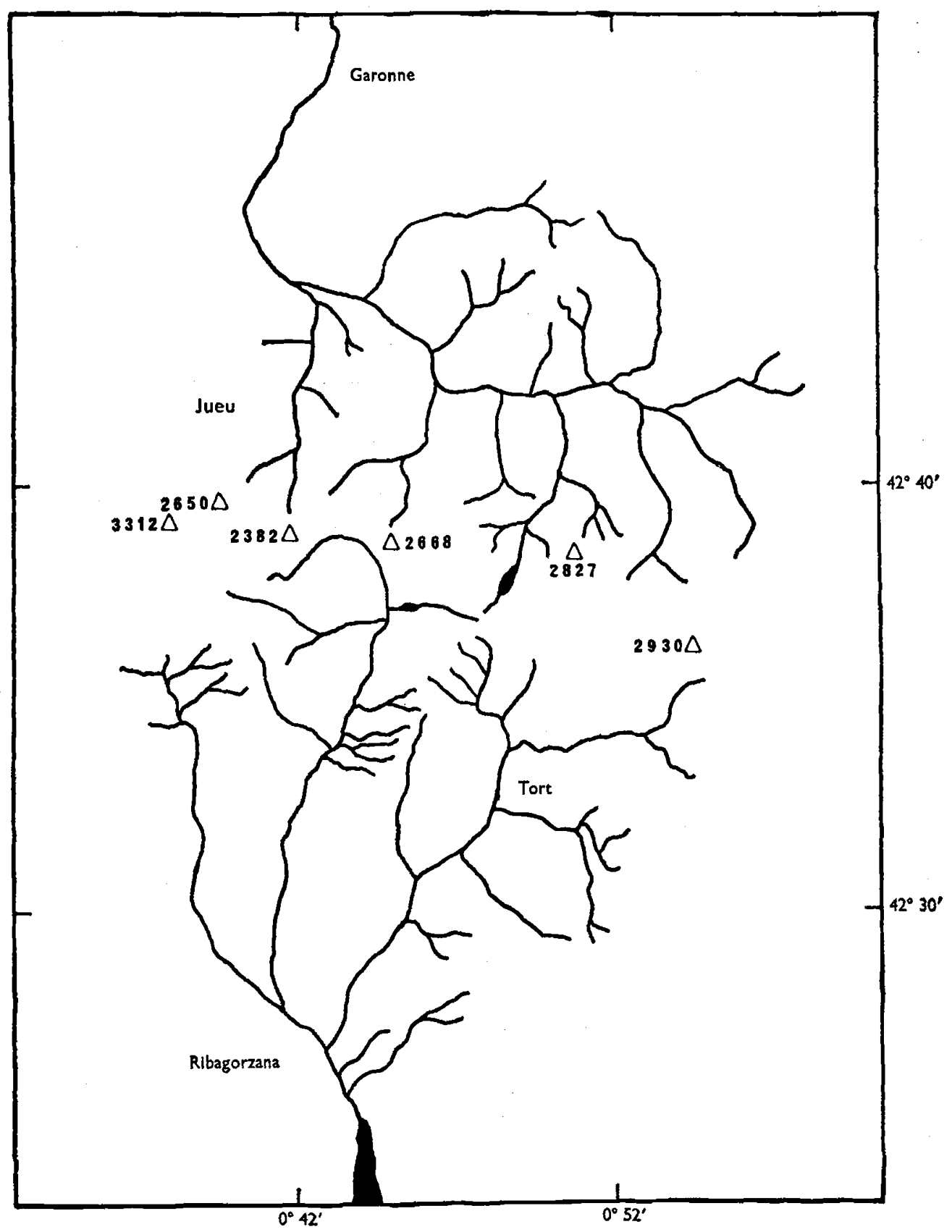

Fig. 1.-Map showing the location of the study areas. 


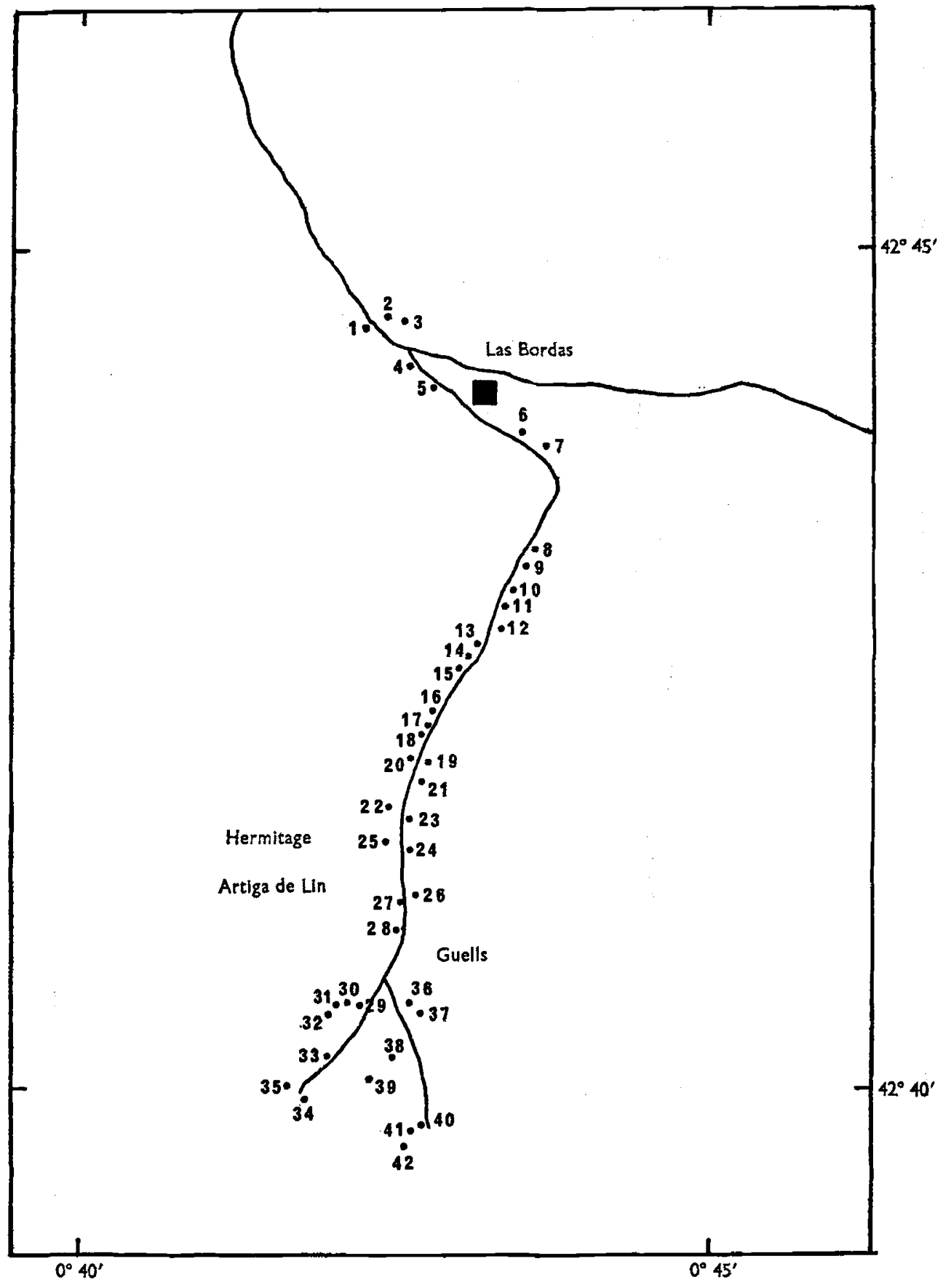

Fro. 2.-Map showing the location of sample sites in the Jueu valley. 


\section{(ii) The Noguera Ribagorzana valley}

Fig. 3 shows the area sampled. The valley is much broader than that of the Jueu, and falls much less rapidly. In contrast to the Jueu, this valley and its neighbour, the Noguera de Tort, face south, and are open to the arid warmth of the Mediterranean climate.

The valley lies on an ancient route to France and bears evidence of settlement right up to its head. In the upper region the more accessible slopes are now marred by signs of degradation-abandoned homesteads at the head and bad gulley-erosion lower down due to forest clearance. The lower reaches of the valley, from Forcat south, are less devastated. There is a flat alluvial bottom covered with hedged fields, and only occasional bluffs and screes provide the shallow soils and dryness comparable to those of the upper degraded area.

\section{(iii) The Noguera de Tort valley}

This valley was sampled from the sides of the artificial Lago Caballers $(1600 \mathrm{~m}$.) down to the junction with the Noguera Ribagorzana near Castel de Tort (fig. 3). The upper regions are wild and rock-strewn, with coniferous woods. In the lower regions the woods are mostly deciduous; here the valley goes through a succession of gorges and wider alluvial areas, the former being wooded and the latter usually cultivated, with hedged fields and villages. Degradation is not so extensive as in the Noguera Ribagorzana valley, but there are areas of scrub and scree, and the southerly exposure permits the appearance of thermophilous species at these sites. Mediterranean influence does not, however, penetrate as far as it does in the Ribagorzana.

\section{Methods}

\section{(i) Sampling and scoring of $C$. nemoralis}

Samples were made by searching small areas of relatively uniform habitat and collecting all specimens of Cepaea found. Where possible, the area searched was less than $400 \mathrm{~m}^{2}$. (the panmictic unit for $C$. nemoralisMurray, 1964), but samples were taken over a larger area when snails were hard to find. Cepaea hortensis (Müll) also occurs in the area, and it was collected when found.

Two visits were made to each valley, one in 1966 and one in 1969. For each site sampled in 1966, the locality and habitat were noted, and for a few of them more detailed botanical notes were made. All samples made in 1969 were accompanied by detailed botanical notes as well as brief descriptions of soil and geology.

Adult shells of $C$. nemoralis were scored for colour and banding (Cain and Sheppard, 1954) and for lip colour (Cook, 1966; Arnold, 1968). Whitelipped forms of $C$. nemoralis are sometimes indistinguishable on external characters from $C$. hortensis. Dissections to reveal the mucous glands and darts were made in cases of doubt (Perrot and Perrot, 1938).

\section{(a) Collection}

(ii) Collection and interpretation of botanical data

The areas studied extend from the Mediterranean to the Alpine zone. Selection and size of each sampling site was dependent on the requirements 


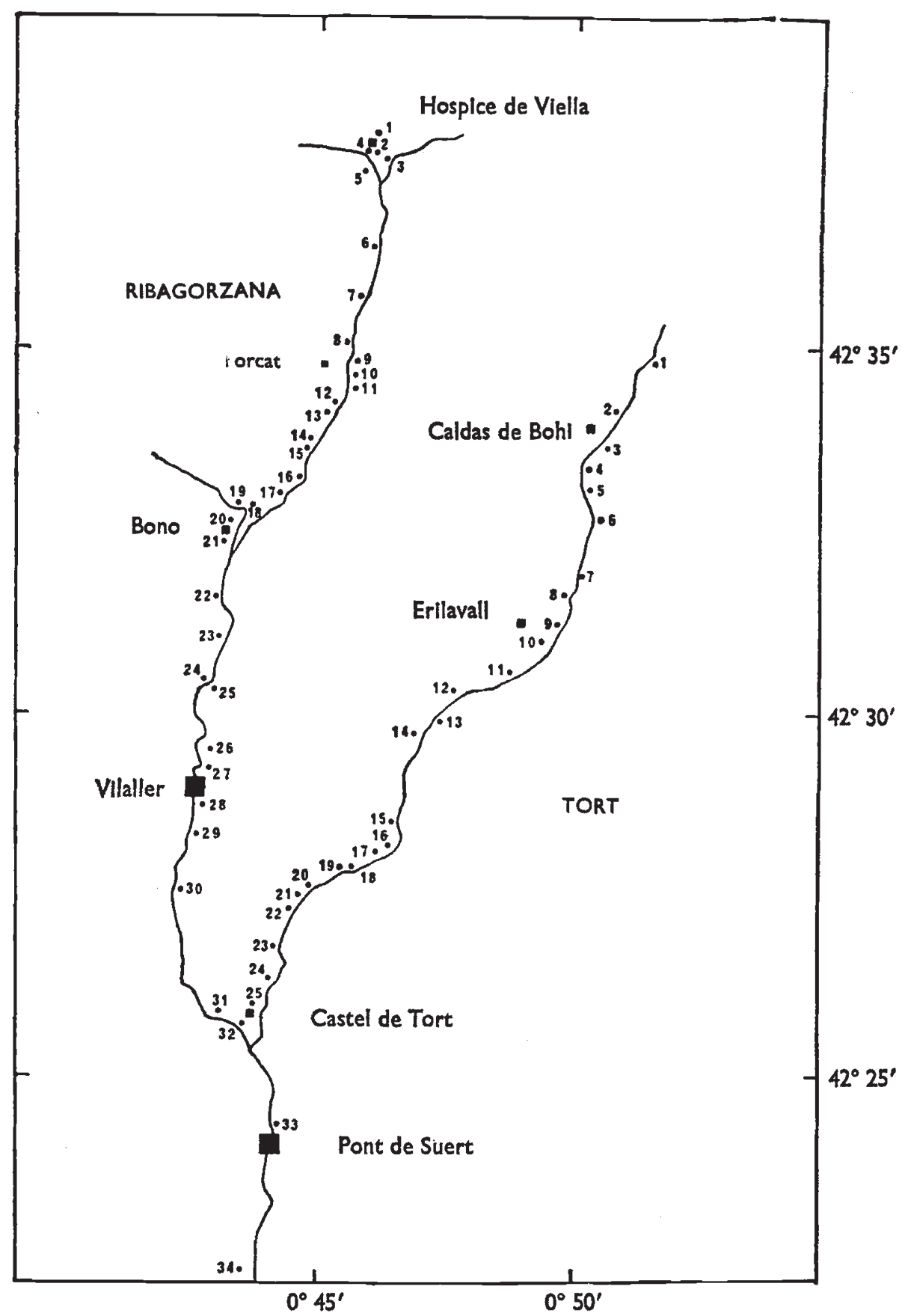

Fig. 3.-Map showing the location of sample sites in the valleys of the Ribagorzana and Noguera de Tort. 
of snail collecting, which sometimes resulted in the sampling of phytosociologically heterogeneous areas. Hence, a comprehensive list of species present at each site would accumulate data, much of which would be useless for ecological or phytosociological interpretation. Recording of species at each site was therefore selective, attention being concentrated on those species likely to be of use as indicators of particular climatic or ecological conditions, and on species characteristic of particular phytosociological associations. Notes were made on the aspect, topography and plant associations found at each site.

\section{(b) Interpretation}

The vegetation of each site was assessed and then assigned to its appropriate climatic type. The species recorded were classified phytogeographically following Oberdorfer (1962), except for a few Pyrenean endemics and strictly Mediterranean species not considered by him, for which we have used information in Coste (1937), Fournier (1961) and Baroni (1955), to assign them to appropriate groups in Oberdorfer's scheme.

Climatic zones have been defined by considering the altitudinal ranges of certain of these species regarded as characteristic of vegetational stages in the Pyrenees (Rivas-Godoy, 1956; Gaussen, 1956; Schmid, 1956). Data for the Noguera Ribagorzana paralleling our own is in Frödin (1927) and Gaussen (1956). We have followed Sappa (1956) in regarding the vegetation of the contact area between Mediterranean oakwoods of Quercus ilex and the next altitudinal zone (Quercus pubescens) as a mixture of floristic elements.

Many phytosociological works, especially Ludi (1956) and Tuxen and Oberdorfer (1958) have been used to classify the vegetation at our sites. We have used their information as a basis for identifying broad and easily categorised units in keeping with the requirements of this study. Only a selection of the species recorded have been used for this purpose, those considered being the dominant, indicative or phytosociologically characteristic species.

Measurements of soil $p \mathrm{H}$ were made colorimetrically at all sites sampled in 1969.

\section{REsults}

\section{(i) The distribution of Cepaea}

C. nemoralis is widely distributed in all three valleys. Below the tree-line is is usually restricted to open habitats such as meadows, scrub and hedgerows, being rare or absent inside woods. Above the tree-line it occurs in most meadows or screes with calcareous soils.

In all three valleys, some attention was paid to establishing the upper altitudinal limits of the species. In the Jueu valley the highest population was found at $c .1900 \mathrm{~m}$. on a north-east-facing slope. Calcareousness of the soil evidently has a pronounced effect on upper limits, for all sites containing C. nemoralis over $1500 \mathrm{~m}$. in the Jueu valley were calcareous. Several acid sites similar in aspect, height and cover were searched without success. Below $1500 \mathrm{~m}$., soil acidity seems to be less limiting.

The heads of both south-facing valleys are made of granitic rocks, and soils are all acid. The highest population in the Noguera Ribagorzana was 
TABLE 1

The occurrence of $C$. hortensis in samples of $C$. nemoralis made in the three valleys, split into altitudinal categories

\section{C. hortensis}

below $1000 \mathrm{~m}$. $1000-1300 \mathrm{~m}$. above $1300 \mathrm{~m}$.

Total

$\begin{array}{rr}+ & - \\ 0 & 9 \\ 4 & 12 \\ 4 & 10 \\ 8 & 31\end{array}$

\begin{tabular}{|c|c|}
\hline Riba & zan \\
\hline+ & - \\
\hline 6 & 8 \\
\hline 9 & 3 \\
\hline 5 & 6 \\
\hline 20 & 17 \\
\hline
\end{tabular}

\begin{tabular}{|c|c|}
\hline \multicolumn{2}{|c|}{ Tort } \\
\hline+ & - \\
\hline 0 & 10 \\
\hline 1 & 9 \\
\hline 3 & 5 \\
\hline 4 & 24 \\
\hline
\end{tabular}

$+=C$. hortensis present; $-=C$. hortensis absent.

found at $1760 \mathrm{~m}$., and that in the Noguera de Tort at $1640 \mathrm{~m}$., both higher than any population on acid rocks in the Jueu.

$C$. hortensis occurs in all three valleys (table 1 ). It occurs with $C$. nemoralis much more often in the Noguera Ribagorzana than in the other valleys, and shows no sign of variation in occurrence with altitude. In the other two valleys it occurs most often at high altitudes.

\section{(ii) Temporal stability of morph frequencies}

Although the Jueu valley has altered little in the last 50 years, except for some abandonment of agriculture, the valley of the Noguera Ribagorzana has changed substantially due to extensive deafforestation and consequent floods and erosion. Collections of $C$. nemoralis made in all three valleys in the early years of this century are reported by Bofill and Haas (1920, 1921). Their samples were often collected over large areas, or from several kilometres of roadsides, and they are not explicitly stated to be random with respect to morphs, although the detailed accounts of the numbers of each variety found, strongly suggest that they are. Many of the samples were very small. Table 2 shows a comparison of the two samples from their papers

\section{TABLE 2}

Comparison of morph frequencies of C. nemoralis between samples recorded by Bofill and Haas (1920, 1921) from Vilaller and Caldes de Bohi with the four samples nearest to each made in 1966-69

Vilaller (Noguera Ribagorzana)

\section{Percentage:}

Unbanded

Yellow

Pink

Brown

White lip in yellow

No. in sample

Caldes de Bohi (Noguera de Tort)

\section{Percentage:}

Unbanded

Yellow

White lip in yellow

No. in sample

\begin{tabular}{rrcrr}
\multicolumn{4}{c}{ Sample } & \multicolumn{2}{c}{} \\
26 & 27 & B \& H & 28 & 29 \\
98 & 96 & 90 & 100 & 95 \\
37 & 40 & 40 & 40 & 47 \\
8 & 3 & 10 & 0 & 0 \\
55 & 57 & 50 & 60 & 53 \\
78 & 69 & 75 & 84 & 85 \\
62 & 30 & 10 & 33 & 45
\end{tabular}

\begin{tabular}{rrrrr}
\multicolumn{4}{c}{ Sample } & \\
1 & 2 & B \& H & 3 & 4 \\
56 & 37 & 45 & 33 & 76 \\
100 & 100 & 100 & 100 & 100 \\
100 & 100 & 100 & 100 & 100 \\
16 & 16 & 20 & 9 & 13
\end{tabular}


which are $(a)$ of reasonable size, $(b)$ located by one place-name only, rather than as between two places. For each of the samples, the comparable frequencies are given for the four sites sampled by us which lie closest to the place named. Considering the sizes of sample involved, the agreement between their samples and our own is close. There is, unfortunately, no exactly located sample from the Jueu for comparison.

In the short term (1966-1969), no appreciable changes in morph frequency have occurred in two sites in the Noguera Ribagorzana (33 and 34) sampled on both visits. Our samples from the mouth of the Jueu valley are closely conformable to Arnold's samples from 1962 in the vicinity.

\section{(iii) Variation in phenotype and chromosome frequencies}

\section{(a) The Fueu valley}

Variation at the major loci. Details of the scores, habitats and altitudes of each sample are given in Appendix 1. Many populations are polymorphic at all three major loci (shell colour, banding and lip colour); but for colour, only yellow and pink shells are found. The midbanded (00300) modifier of banding is locally common, but other modifiers of banding are rare or absent.

Linkage disequilibria. The three major loci are tightly linked (Cain, Sheppard and King, 1968). Table 3 shows the directions and consistency of the possible disequilibria in samples from the Jueu. The five samples in

TABLE 3

Linkage disequilibria in samples of $C$. nemoralis from each of the valleys. The "Number of samples" columns show the number of samples in which the morph concerned is in excess in each class of morphs at a different locus. Only samples in which both possibilities can occur are included

\begin{tabular}{|c|c|c|c|c|}
\hline \multirow{2}{*}{$\begin{array}{l}\text { Morph } \\
\text { fueu }\end{array}$} & \multicolumn{2}{|c|}{$\begin{array}{l}\text { Number of samples } \\
\text { Excess in: }\end{array}$} & \multirow{2}{*}{$x_{1}^{2}$} & \multirow{2}{*}{$\mathbf{P}$} \\
\hline & Yellows & Pinks & & \\
\hline White lip & $\begin{array}{c}21 \\
\text { Unbandeds }\end{array}$ & $\begin{array}{c}5 \\
\text { Bandeds }\end{array}$ & $8 \cdot 30$ & $<0.01$ \\
\hline White lip & $\begin{array}{c}21 \\
\text { Yellows }\end{array}$ & $\begin{array}{c}1 \\
\text { Pinks }\end{array}$ & $18 \cdot 2$ & $<0.001$ \\
\hline Banded & 16 & 8 & $2 \cdot 67$ & $>0.1$ \\
\hline $\begin{array}{l}\text { Ribagorzana } \\
\text { White lip }\end{array}$ & $\begin{array}{c}\text { Yellows } \\
16\end{array}$ & $\begin{array}{c}\text { Browns } \\
0\end{array}$ & $16 \cdot 00$ & $<0.001$ \\
\hline White lip & $\begin{array}{l}\text { Yellows } \\
26 \\
\text { Unbandeds }\end{array}$ & $\begin{array}{c}\text { Pinks } \\
1 \\
\text { Bandeds }\end{array}$ & $22 \cdot 21$ & $<0.001$ \\
\hline White lip & $\begin{array}{l}12 \\
\text { Yellows }\end{array}$ & $\begin{array}{c}3 \\
\text { Pinks }\end{array}$ & $5 \cdot 40$ & $<0.05$ \\
\hline Banded & 12 & 3 & $5 \cdot 40$ & $<0.05$ \\
\hline Tort & Yellows & Pinks & & \\
\hline White lip & $\begin{array}{c}1 \\
\text { Unbandeds }\end{array}$ & $\begin{array}{c}12 \\
\text { Bandeds }\end{array}$ & $10 \cdot 09$ & $<0.01$ \\
\hline White lip & $\begin{array}{c}10 \\
\text { Yellows }\end{array}$ & $\begin{array}{r}7 \\
\text { Pinks }\end{array}$ & $0 \cdot 26$ & $>0 \cdot 1$ \\
\hline Banded & 11 & 2 & $6 \cdot 15$ & $<0.05$ \\
\hline
\end{tabular}


which white lip is associated with pink shells $(24,23,14,25,28)$ are clustered together near the Ermitage d'Artiga de Lin.

Variation in phenotype frequency with altitude, habitat and topography. Fig. 4 shows the variation in some morph frequencies with altitude. The frequency of white lip in yellow shells, rather than overall frequency, is shown, following Arnold (1968). Taking account of habitat and topography, there are clear altitudinal trends in morph frequencies. Yellow and unbanded increase with altitude. Both are at, or near, fixation in all samples above the Guells de Jueu. White lip in yellow shells is also at or near fixation above the Guells, but varies in a more complex way below them.
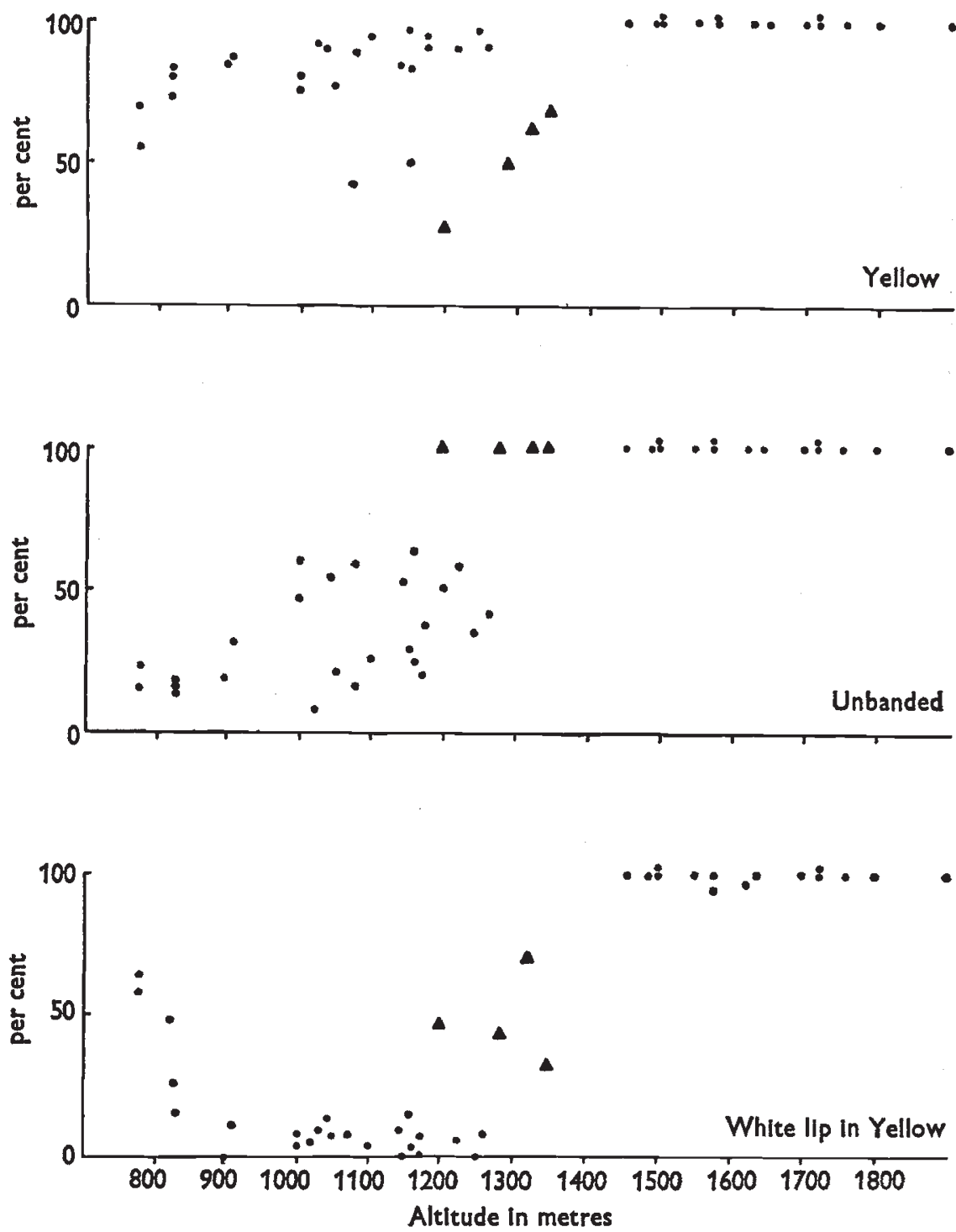

FIG. 4. - The variation of certain morph frequencies with altitude in samples from the Jueu valley. $\Delta=$ samples from woods. 
Most samples were made close to the valley bottom (Arnold, 1968), but we have five samples from hillsides along the track past Artiga de Lin. The frequencies of unbanded and white lip in yellow in these samples is slightly lower than would be expected from a consideration of valley bottom samples alone.

Four samples come from woods round the Guells de Jueu, all from woodedge or other disturbed sites. These samples, and two others lower down the valley from thick hedgerows, have strikingly lower frequencies of yellow shells than would be expected from the remainder. Within the four woodland samples, the frequency of yellow increases with altitude. All the occasional C. nemoralis found in woods above the Guells (i.e. $1500 \mathrm{~m} .+$ ) are yellow.

Variation in chromosome frequencies. The linkage disequilibria and parallel variation in morph frequencies seen in these samples suggest that variations in frequency of certain allelic combinations of the three major loci may show trends not seen in the variation at each locus considered separately. The frequencies of the possible allelic combinations (" chromosomes ") have been computed using a maximum likelihood method (Cepellini, Siniscalso and Smith, 1955). Variation in chromosome frequencies with altitude is shown in fig. 5. The changes in chromosome frequencies with altitude are more regular than changes in morph frequency. The variations of the two yellow white-lipped chromosomes are very distinct, and account for the bimodal variation in frequency of white lip in yellow.

\section{(b) The Noguera Ribagorzana valley}

Variation at the major loci. Full scores and notes on each sample are in Appendix 2. Pink, yellow and brown shells are present, as are banded and unbandeds. Unlike the Jueu, modifiers of banding other than midbanded are locally common, especially at the southern end of the valley. Punctate banded shells, and shells with the top two bands missing (00345) are the most frequent. Many populations are polymorphic for lip colour.

Linkage disequilibria. Table 3 shows the observed disequilibria in the samples. White lip is strongly associated with yellow shell, and also with unbanded. Yellow and banded are also associated. All brown shells are unbanded.

Variation in phenotype frequency with altitude, habitat and topography. Fig. 6 shows the variation in various morph frequencies with altitude. There are trends in colour-morph frequencies with altitude, pink being frequent at high altitudes and brown at low. There is a wide scatter of frequencies of brown within the area in which it occurs, and many samples within the area have no browns at all.

Unbanded shells are usuallyat very high frequencies (often 100 per cent.). The phenomenon is more marked if the frequencies of "effectively unbanded" shells (those in which the top two bands are missing-Cain and Sheppard, 1954) are considered. Normal five-banded shells occur at high frequencies only at the head of the valley. Variation in frequency of white lip in yellow shells is not so clearly related to altitude.

All samples from this valley were made near the valley bottom, with the exception of the uppermost three samples (from a hillside overlooking the valley head) and the bottom two (on hillsides overlooking the reservoir south of Pont de Suert). The top three are different from others in the frequencies 


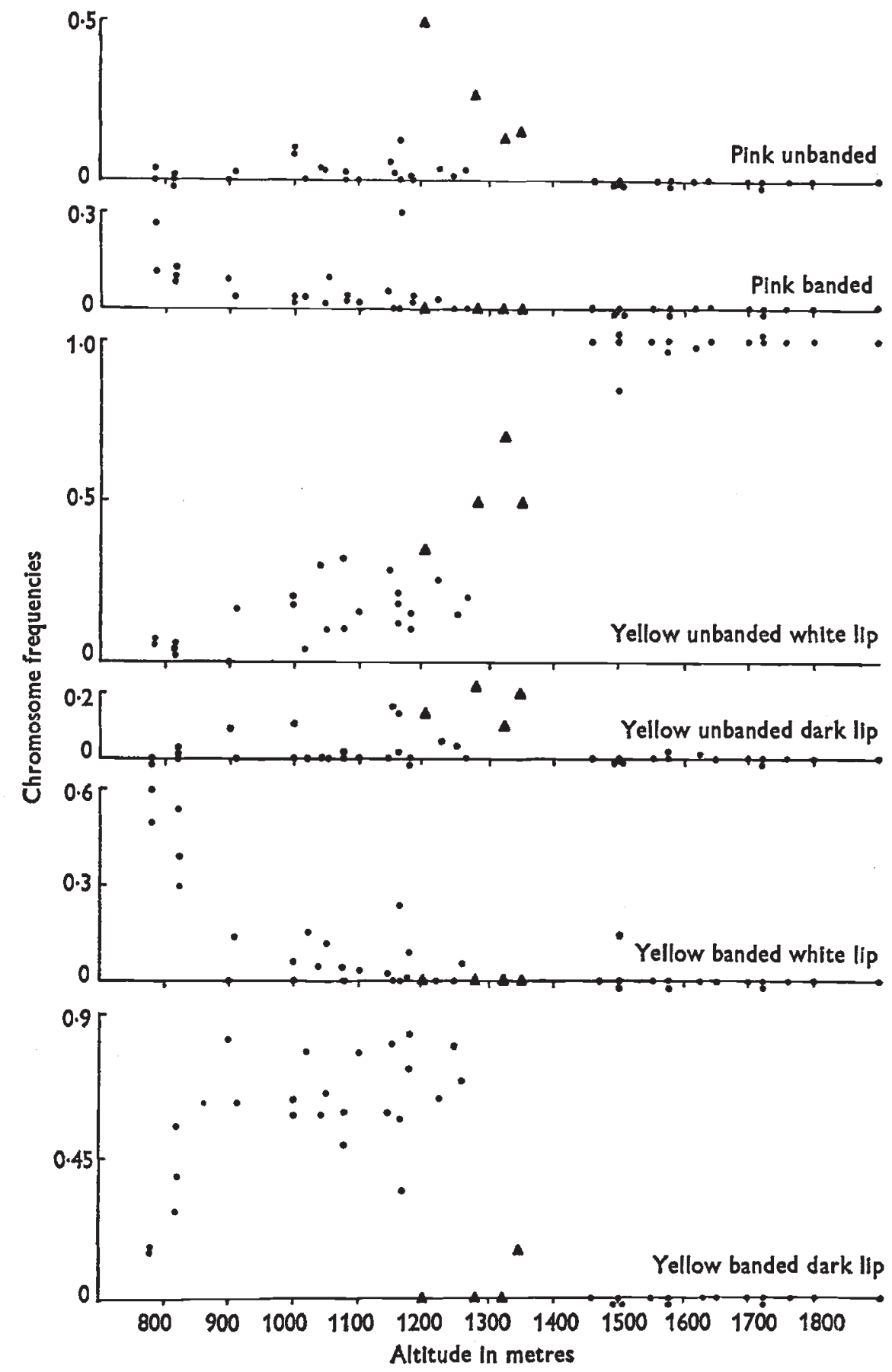

Fro. 5.-The variation of certain chromosome frequencies with altitude in samples from the Jueu valley. $\boldsymbol{\Delta}=$ samples from woods. 
of banded. No samples were made from woods, and the main divisions of habitat are between scrub and hedgerows (see below).

Chromosome frequencies. Of 12 possible chromosomes, three do not occur at all (both brown-banded chromosomes and pink-banded white lip) and
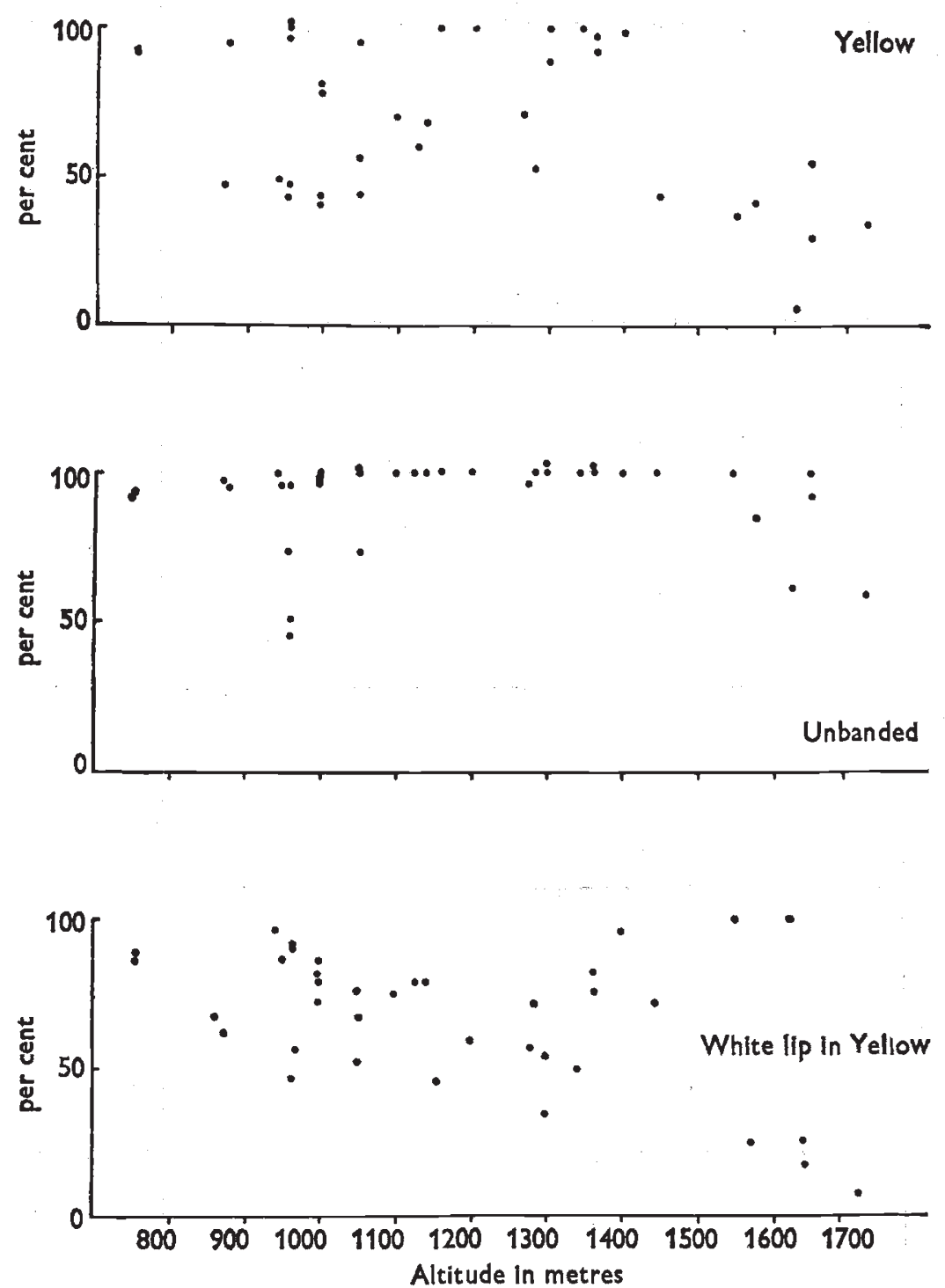

FIG. 6.-The variation of certain morph frequencies with altitude in samples from the Ribagorzana valley.

one (pink-banded dark lip) is restricted to the four highest samples. Variations in frequency of some of the remainder with altitude is shown in fig. 7. Patterns similar to those seen in morph frequencies occur, but variation with altitude is not clear-cut. 

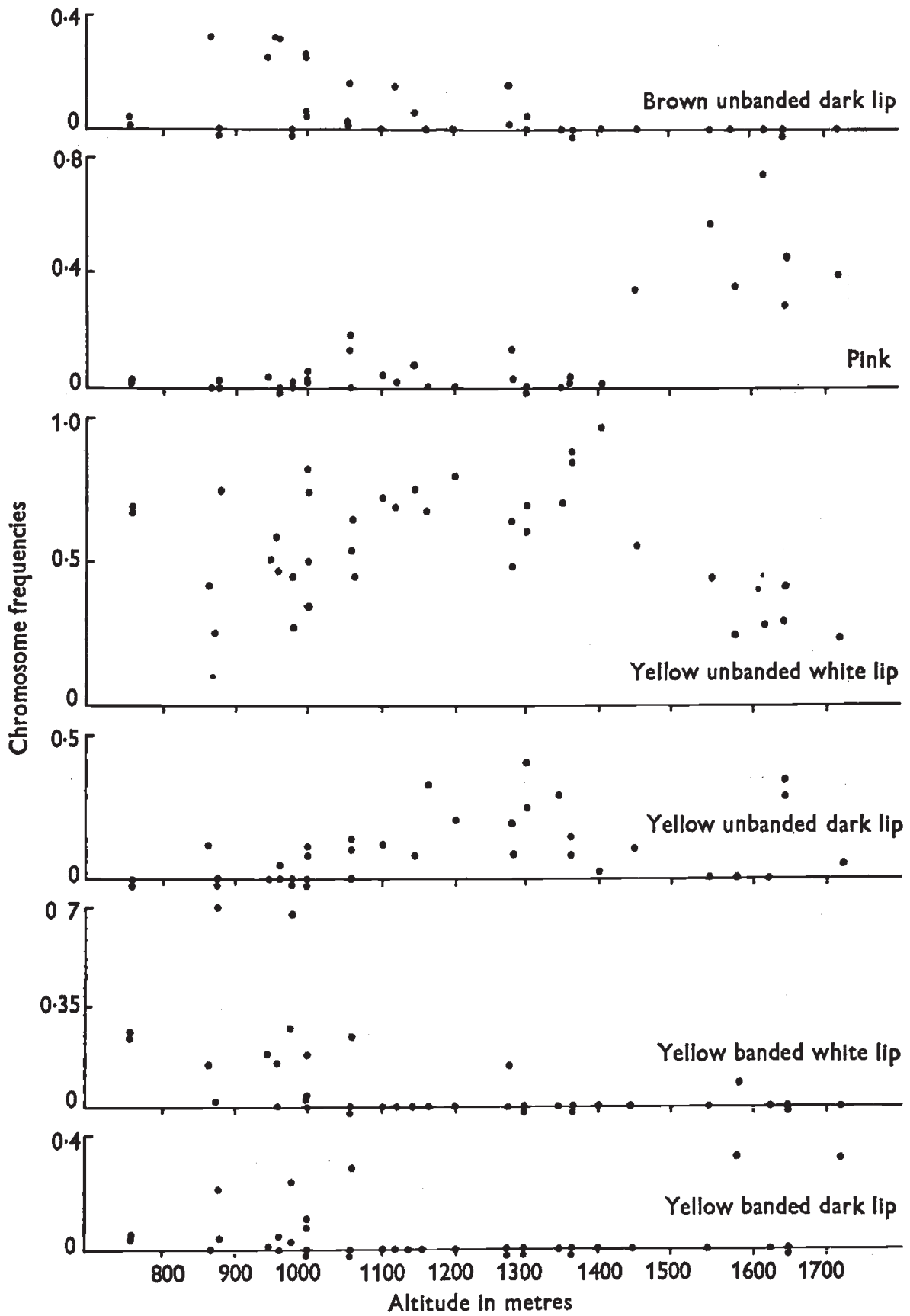

FIG. 7.-The variation of certain chromosome frequencies with altitude in samples from the Ribagorzana valley. 


\section{(c) The Noguera de Tort valley}

Variation at the major loci. Full scores and habitat notes on the samples are given in Appendix 3. Yellow and pink shells are widely distributed, but brown shells are present only in the two lowest samples (24 and 25) near the junction with the Noguera Ribagorzana. Many populations are polymorphic for banding and lip colour.
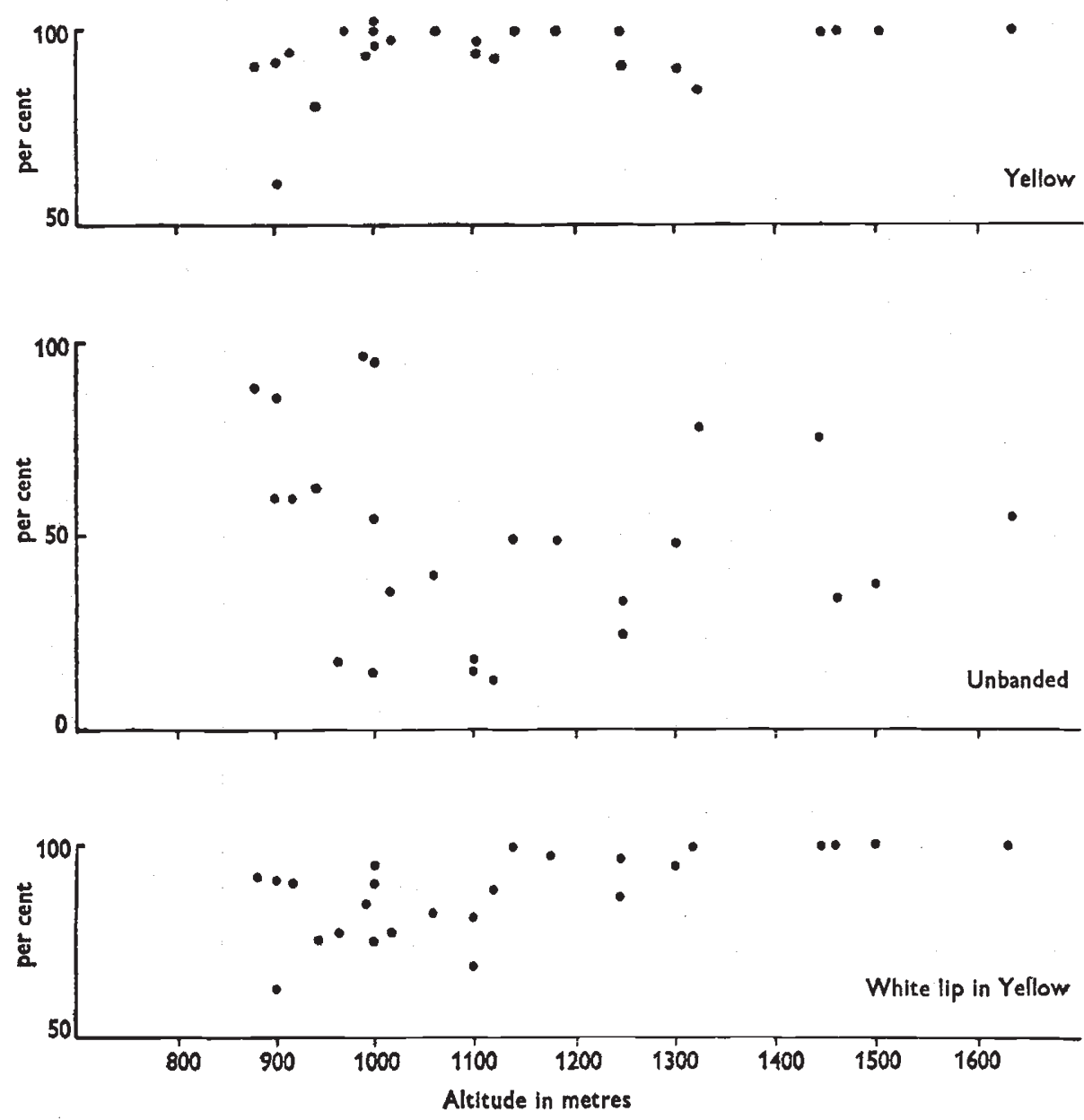

Frg. 8.-The variation of certain morph frequencies with altitude in samples from the Tort valley.

Linkage disequilibria. Table 3 shows the observed disequilibria in the samples. Unlike the other valleys, there is an association between white lip and pink shell, the two exceptions being the lowest samples near the junction with the Noguera Ribagorzana. There is no association between lip colour and banding, but, as in the other valleys, bandeds are in excess in yellow shells.

Variation in phenotype frequency with altitude. Only white lip in yellow shells shows changes clearly associated with altitude. All samples were from or near the valley bottom, and none were made in woods. 
Variation in chromosome frequencies. There are no major trends in chromosome frequency variation not seen in morph frequencies. The two yellow white-lip chromosomes (banded and unbanded) are the most frequent. Dark-lip chromosomes are rare and restricted to the lower part of the valley.

\section{(iv) Morph frequency variation in relation to habitat and vegetational zonation}

\section{(a) The delimitation of vegetation zones}

We have used the well-documented sequence of European vegetational zones: Mediterranean, Sub-Mediterranean, Sub-Montane, Montane, SubAlpine and Alpine, each defined by characteristic species and species associations (Ellenberg, 1963). By extracting data on such species from our records, we have delimited the vegetational zones in each valley and placed each sample site in a zone. Fig. 9 shows the altitudinal ranges of the species concerned in each valley, and fig. 10 the altitudinal limits adopted by us for each zone. For the Noguera Ribagorzana we have used additional information in Rivas-Godoy (1956).

The altitudinal zonation in fig. 10 applies strictly to the valley bottoms, and to natural climax vegetation. There are many areas in all three valleys where local topography or clearance causes microclimatic variations which permit the development of floras atypical of their zone. The existing treeline in the Jueu is largely man-made, and considerably lower than the natural one. The meadows in the cirques at the valley head are surrounded by woods on three sides and lie, therefore, in the Montane zone. They contain, however, many plants characteristic of the Sub-Alpine zone, and represent an extension of that zone below its normal limits. All samples above $1450 \mathrm{~m}$. are from this cleared area, and are regarded as Sub-Alpine rather than Montane. At the valley mouth, there is some mixing of Montane and Sub-Montane zones.

In the Noguera Ribagorzana and Noguera de Tort valleys the upper limit of $C$. nemoralis is below the Sub-Alpine zone. In both valleys, the Montane zone is rather sharply demarcated from those below. Below the Montane zones of the two south-facing valleys, the usual altitudinal zonation is very much upset by clearance and agriculture, and the natural limits of each zone have little relevance to the habitats occupied by $C$. nemoralis. The lowest part of the range (below $900 \mathrm{~m}$.) is characterised by Mediterranean vegetation. Above this, right up to the borders of the Montane zone $(1400 \mathrm{~m}$.), Mediterranean species and assemblages are found whenever there are suitable combinations of southerly aspect, thin soil, and sparse plant cover. Buxus sempervirens and Genista scorpeus are characteristic of such areas. Conversely, areas less subject to intense insolation, such as Prunus spinosa hedges and tall herb communities have floras more typical of the SubMontane zone to which they belong altitudinally. The upward extension of Mediterranean plants is more marked in the Ribagorzana than in the Tort, which reflects the greater degree of clearance in the former valley.

\section{(b) Morph frequencies, vegetational zones and habitat}

As shown above, there are a number of altitudinal and habitat trends in morph and chromosome frequencies in $C$. nemoralis populations in the area. One would therefore expect to find some degree of correlation between morph frequencies and vegetational zonation within each valley. If those 


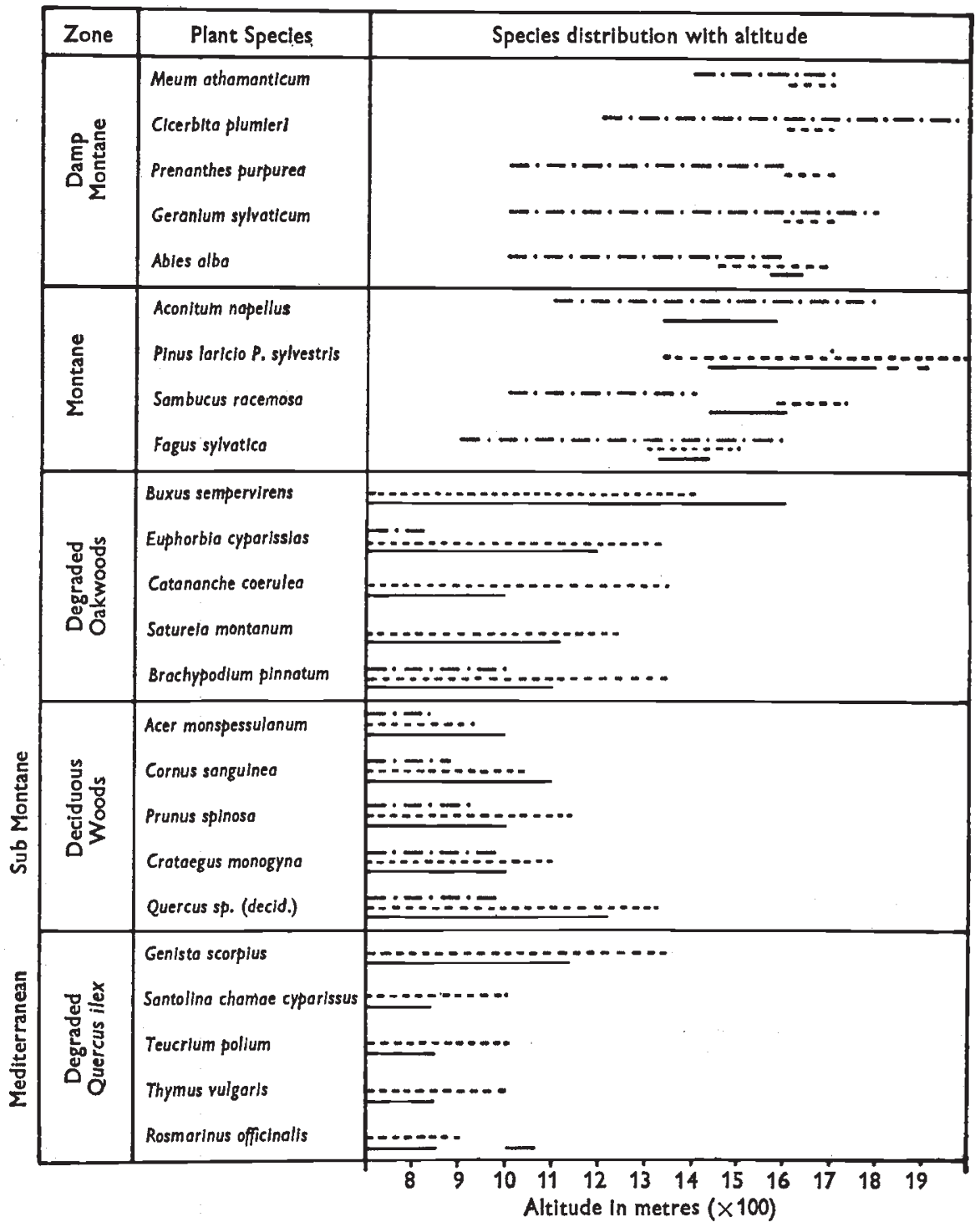

Fro. 9.-The altitudinal distribution of plant species characteristic of certain vegetational zones in the three valleys studied. - . - range in the Jueu valley, ... range in the Tort valley, — range in the Ribagorzana valley.

aspects of climate reflected in vegetational zonation are important factors affecting morph frequencies, we might expect that each zone within each valley will be characterised by a distinctive set of morph frequencies (differences in habitat being taken into account) and also, that there will be some correspondence in morph frequencies between samples from the same climatic zone in different valleys.

Within each valley there is evidence that samples from each habitatvegetation zone category do have a distinctive set of morph frequencies. 
Fig. 11 shows the scatter of yellow and unbanded frequencies for samples from the Jueu valley for which we have detailed information on both habitat and zone. Samples from the open Sub-Alpine zone are clearly distinct from all other samples. It is worthy of emphasis that samples from this zone cover not only a great range of altitudes, but also a considerable range of nonwooded habitats, from dense tall herb communities on talus slopes to much shorter sub-alpine pasture on thick soil.

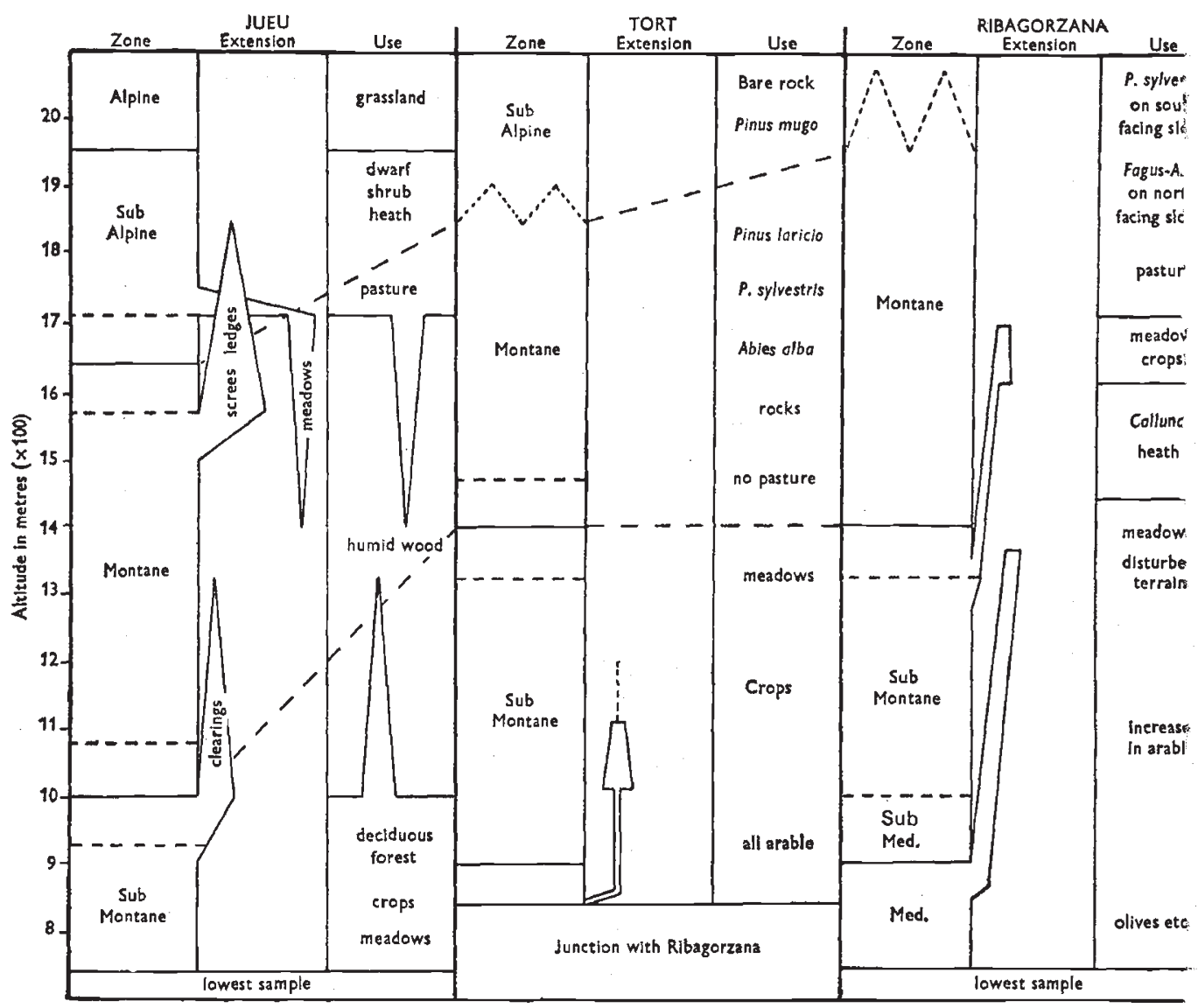

FIG. 10.-A diagram showing the altitudinal sequence of plant zones in the three valleys. The zone column shows the range of each vegetational zone under natural conditions. The extension column shows all the major instances of the extension of plants outside the altitudinal limits of their normal zone and the use column gives an indication of the predominant vegetational types in each zone.

With the Montane and Sub-Montane zones, the only distinction in habitat which appears to be important in relation to morph frequencies is that between woods and the rest (see above).

There is some overlap between the Montane and Sub-Montane zones in morph-frequency distribution. Banded white-lipped shells are particularly characteristic of the Sub-Montane zone.

There are likewise characteristic habitat-vegetation zone clusters in the Noguera Ribagorzana valley samples (fig. 12.) Montane zone samples are 
characterised by high frequencies of pink shells, and browns are completely absent. It is in this zone alone that banded shells reach high frequencies; within it they are found only in the three highest samples, all on hillsides as opposed to on the valley floor below.

Below the Montane zone, morph frequencies do not segregate neatly into clumps by vegetation zone alone. No samples have high frequencies of pink, but variation in yellow and brown is considerable within each of the three zones involved. The samples for which we have adequate botanical data

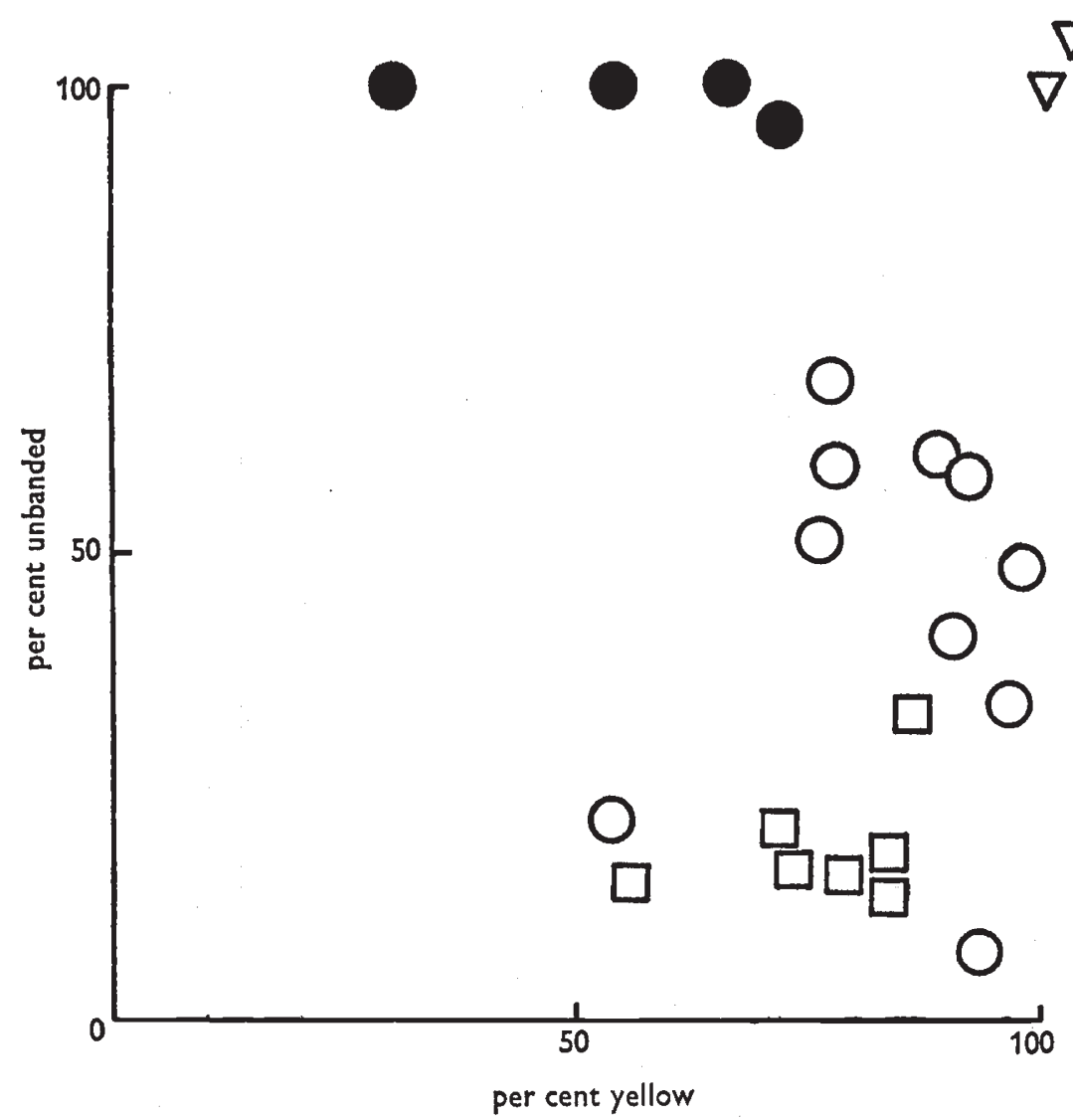

Fic. 11.-The scatter diagram for percentage yellow and percentage unbanded for samples in the Jueu valley for which there are detailed botanical notes. $\square=$ Sub-Montane samples. $O=$ Montane samples in open habitats. $\quad=$ Montane samples from woods. $\nabla=$ Sub-alpine samples.

may be split into three classes. Firstly, open scrub, dominated by Buxus, with much bare soil. The lowest three sites in this class lie within the Mediterranean zone, and have more cover than the rest, but a similar assemblage of plants. Genista scorpeus is found in all but the uppermost two sites, and its altitudinal range in this valley is clearly extended by $c .300 \mathrm{~m}$. in the presence of these bare areas subject to high isolation.

The second class of site is really a variant of the first, with the same 
general vegetation. In the two sites concerned however, a watercourse ran through the sample area, its sides covered with much thicker vegetation and on thicker and damper soil. Snails were collected from all vegetation in the area, but more were found in the thick vegetation at the water's edge. The third class is heterogeneous, but has a common property of more complete ground cover and a much denser herb layer.

These three habitat classes contain distinctive colour-morph frequencies. The Buxus scrub series have little or no brown, the intermediate pair both have low frequencies, and the hedgerow series have frequencies of brown all

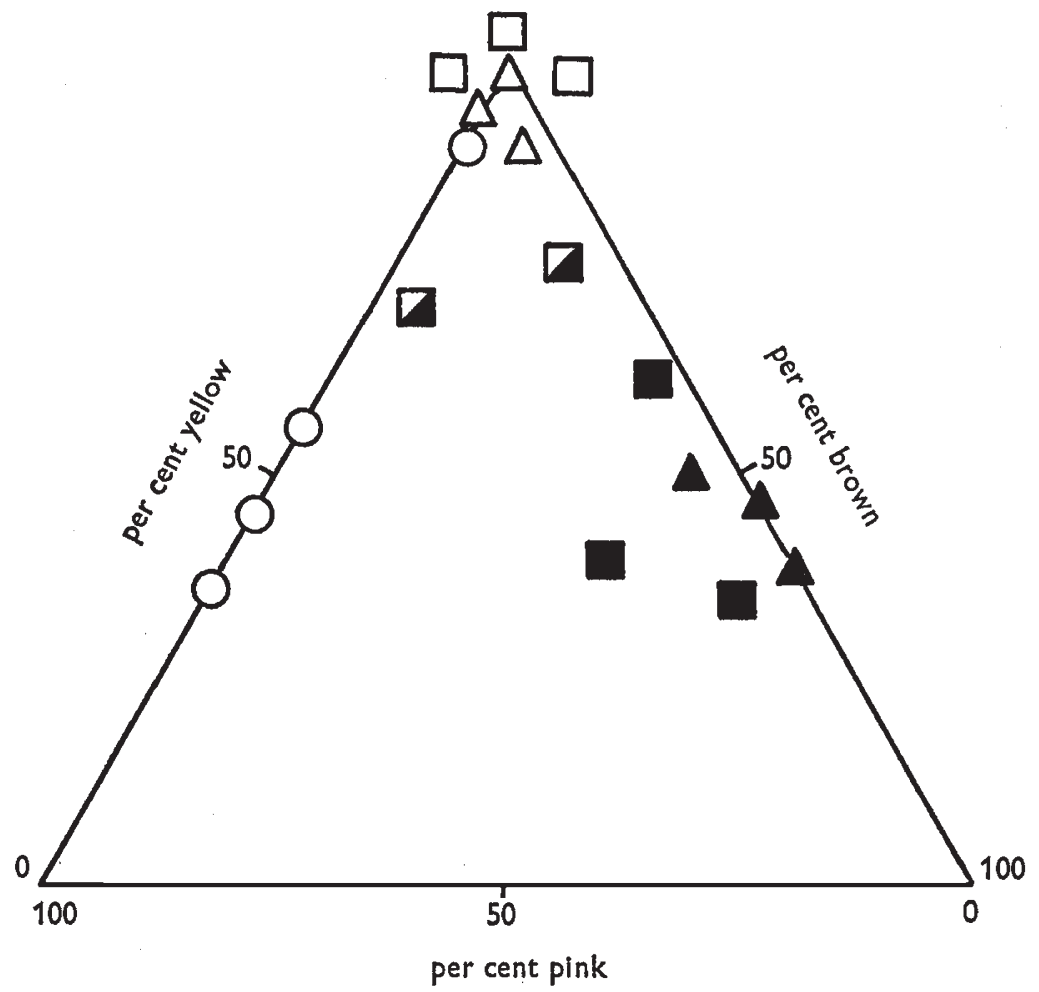

Fro. 12.-The scatter diagram for colour morphs for samples from the Ribagorzana valley for which there are detailed botanical notes. $O=$ Montane samples. $\square=$ SubMontane samples in hedgerows. $\square=$ Sub-Montane samples in scrub. $\bar{\nabla}=$ SubMontane samples from intermediate habitats. $\boldsymbol{\Delta}=$ Mediterranean and Sub-Mediterranean samples from hedgerous. $\Delta=$ Mediterranean and Sub-Mediterranean samples from scrub.

in excess of 35 per cent. The scrub series could be classed as broadly "Mediterranean" in type; those from the hedgerow series as "SubMontane".

There is a similar range of habitats below the Montane zone in the Noguera de Tort valley, but the pattern of morph frequency variation seen in the Noguera Ribagorzana is not repeated here. Of the meadow-hedge series only the lowest two nearest the junction with the Ribagorzana contain any brown shells. Even the samples from the Montane zone are not markedly 
different from the rest, although it is only here that both yellow and white lip consistently reach fixation.

Comparisons between valleys show that there are not, as a rule, similar morph frequencies in the same zone of each. Even trends in morph frequency changes are inconsistent between valleys. It is, perhaps, facile to expect close similarities between the Jueu and the other two valleys, lying on opposite sides of a high mountain range, but the differences between the two south-facing valleys are as marked in spite of the similarities in geology, aspect and habitats.

\section{Discussion}

\section{(i) The distribution of $C$. nemoralis}

Large thick-shelled species of snail tend to become more calcicole near the limits of their range (Boycott, 1934). This phenomenon would appear to explain the higher altitudinal limit of $C$. nemoralis in the north-facing Jueu valley as opposed to the two south-facing ones. When non-calcareous soils alone are considered, the upper altitudinal limit is highest in the southfacing valleys. Arnold (1968) found that the upper limits of $C$. nemoralis in valleys of the upper Garonne varied between 1420 and $2100 \mathrm{~m}$. He did not consider the effects of geology on the upper limit, but with the aid of a large-scale geological map (Kleinsmiede, 1960), it is possible to determine the geology around and above his highest samples in each valley. In two valleys where limestones occur far up the mountains, his highest samples were made at $1840 \mathrm{~m}$. (Ynola) and $1860 \mathrm{~m}$. (Saliente). In valleys without limestone, or without its extension above $1500 \mathrm{~m}$., the highest samples were lower: Aiguamoix 1520 m., Valarties 1420 m., Negro 1500 m., Barrados $1500 \mathrm{~m}$. and Garona de Ruda $1490 \mathrm{~m}$. His two hillside series rise to $1940 \mathrm{~m}$. and $1910 \mathrm{~m}$., both on calcareous rocks, at least at the upper end. The outstanding exception is the Malo valley, where his highest sample, at $2100 \mathrm{~m}$., is far from any calcareous rocks.

In terms of vegetation zones, it appears that the upper limits of $C$. nemoralis lie about midway through the Montane zone on non-calcareous rocks, with an extension well into the Sub-alpine on limestone.

Except in areas above the tree-line, $C$. nemoralis is usually restricted to man-made habitats. It is rare or absent in woods, where it is frequently replaced by $C$. hortensis.

(ii) The interpretation of botanical data as indicators of climatic conditions

Arnold (1968, 1969) used evidence on the altitude, topography, habitat and geographical positions of his samples to demonstrate the operation of climatic selection on $C$. nemoralis in the Pyrenees. In order to extend his convincing results, it is desirable to specify the climatic regimes in which particular morph and chromosome frequencies occur. We have tried to do this by using data on the well known and widespread altitudinal zonation of plants. Studies of such zonation in areas where $C$. nemoralis varies with altitude might enable some conclusions to be drawn. There are, however, a number of practical and theoretical difficulties in the procedure.

Much of the work on the altitudinal and geographical zonation of plants relates to description of the altitudinal ranges not of individual species, but of characteristic plant associations. Recognition and delimitation of such 
natural assemblages is a more sensitive and accurate way of defining zones than the use of altitudinal ranges of individual species. Information on such natural assemblages is hard to obtain, because of extensive and prolonged human influence in the areas of study, and because $C$. nemoralis, below the Sub-alpine zone, is generally restricted to such obviously man-made habitats as hedgerows, scrub, and roadside verges. The first problem is partially overcome by the recognition of certain characteristic plant assemblages resulting from the alteration of particular natural communities (e.g. the degraded Quercus ilex and $Q$. pubescens assemblages-Rivas-Godoy, 1956). The second problem is aggravated by the presence in such habitats of ephemerals, pioneers and others, possibly normally restricted to other zones, which may flourish in the absence of competitors present in the natural environment.

The man-made nature of $C$. nemoralis habitats raises a further difficulty. There may be considerable heterogeneity of plant associations within the area of panmixis for $C$. nemoralis. Floral homogeneity could be obtained by sampling very small areas, but such an approach could give misleading results if individual snails can and do move in and out of the area frequently. Samples 14 and 25 from the Ribagorzana (cf page 62) demonstrate this situation in an acute form. We have not restricted our sampling area in such conditions, but have accepted the heterogeneity involved.

There is a more general difficulty in the climatic interpretation of botanical data. It cannot be assumed that the climate is the same in all areas belonging to the same vegetation zone, even where natural climax vegetation is present. Each zone covers a range of climatic conditions. Given detailed botanical information it is possible to analyse some of the variation with zones. For example, in the Montane zone a division can be made between damp Montane, with Fagus and Abies as natural dominants, and dry Montane with Pinus as the usual dominant (Gaussen, 1956). We have used such information where possible, but the amount available which is relevant to our study is very limited. There seems to have been little attempt to correlate specific plant assemblages with specific combinations of meteorological conditions.

We have, therefore, used our botanical data in the following, limited ways:

By use of data on the distribution of plant assemblages and of individual indicator species, we have determined approximate altitudinal limits for each vegetation zone.

By study of the floras of individual sampling sites, we have identified extensions of the climatic influence of particular zones into areas where they would not otherwise be expected.

We take it that, although there is a broad range of climate within each zone, the climates of sites within the same zone, and with the same habitat and type of plant assemblage, will be more similar to each other than to those of sites lying in different zones, or with different habitats and plant assemblages. This will be true only for those aspects of climate which exercise important influences on plant zonation. Some climatic variables may vary less from zone to zone within a district than between districts in the same zone, and such variables may influence morph frequencies in $C$. nemoralis. 


\section{(iii) Climatic selection as an explanation of the observed variation}

\section{(a) Within-valley variation}

There are two kinds of regularity in morph frequency variation in our samples-with altitude and vegetational zonation, and with habitat. Most of these regularities suggest the operation of climatic selection. In the Jueu there is a sequence of changes in morph and chromosome frequencies with altitude, and zones of frequency change correspond to changes in plant zones.

Comparison with other tributary valleys of the Garonne, sampled by Arnold, is possible on an altitudinal and general climatic basis. The Jueu differs from the others in being the most densely forested, in having the least number of days with snow lying and in having the highest rainfall (Rijckborst, 1967). The presence of Buxus sempervirens in the Valarties indicates that the valleys at the eastern end of the Valle de Aran are substantially drier than the Jueu.

Variations in frequencies of banding and colour morphs in the Jueu are similar to those in other Aranese tributaries. High frequencies of fivebanded shells occur at greater altitudes in the Jueu than in most other valleys, which might be expected as its climate is warmer and wetter than those of the others (Lamotte, 1966). The Jueu differs from other tributaries, however, in the variations in frequency of lip-colour morphs and chromosomes. There is an increase in the frequency of white lip in yellow shells with altitude in the Valle de Aran as a whole. In the Jueu there is a decrease in frequency with altitude at the valley mouth, a range with very low frequencies, followed by increases to fixation in the Sub-alpine zone. Traces of such a reversal occur in the Valarties, but not elsewhere. The area of very low frequencies of white lip in the Jueu is confined to the Montane zone. Possibly, the more extensive clearance in other valleys has reduced the influence of montane climate on them. Evidence for such effects can be seen in the downward extension of sub-alpine conditions in cleared areas at the head of the Jueu, and from the upward extension of Mediterranean conditions in cleared habitats in the Noguera Ribagorzana. A similar double peak of white-lip frequencies occurs in $C$. nemoralis populations in the Ariege valley (Lamotte, unpublished).

Variation at the shell colour and banding loci between samples from woods and those from more open habitats does not seem related to climate. Woodland samples have higher frequencies of pink and of unbanded shells than do samples from comparable altitudes in open habitats. This difference is similar to that in areas where visual selection for crypsis is effective (Cain and Sheppard, 1954; Currey, Arnold and Carter 1964). It is distinct from the kind of variation with habitat ascribed by Lamotte (1966) to climate selection, where frequencies of pinks and banded are higher in the more shaded habitats. The woodland samples were the only ones made which had high frequencies of thrush-predated shells, suggesting that visual selection is effective only in the woods, a situation paralleled elsewhere (Arnold, 1971).

Of the two valleys south of the Pyrenean watershed, the Noguera de Tort provides by itself little convincing evidence of climatic selection. In the more extensively sampled Noguera Ribagorzana, there are distinct altitudinal and habitat trends in colour and banding morph frequencies. Banded shells are at high frequencies only on south-facing slopes in the Montane zone; 
directly below, on the valley floor in the same zone, most populations are at fixation for unbandeds. This topographical effect in the upper parts of the range of $C$. nemoralis is similar to that described by Arnold (1968) for the Valle de Aran.

In lower parts of the valley, shell-colour morph frequencies are clearly related to habitat, variation in which is in turn related to climate at the local level. The occurrence of dark shells in shady and damp places is in accord with general expectations (Lamotte, 1966) although confirmatory resistance experiments have never been made using brown rather than pink shells against yellows.

\section{(b) Regional and between-valley variation}

Arnold (1968), in his study of two valley systems, one north of the watershed (the Garonne) and one south (the Segre-Valira system), compared within and between systems variations. Although the internal consistency of results within the Segre-Valira complex was not as great as within the Garonne, Arnold was able to make convincing comparisons between the two systems, after making allowances for differences in rainfall and aspect. Variation at the banding locus in particular suited a relatively straightforward climatic interpretation, while variation in shell colour and lip colour left certain anomalies.

By contrast, patterns of variation in the Noguera Ribagorzana and the Noguera de Tort are conformable neither with each other, nor with the Valle de Aran, nor with the Segre. From rainfall and vegetation data (Atlas de France; Gaussen, 1956), they appear to have higher rainfall and lower limits for Mediterranean vegetation than the Segre-Valira. Rainfall in the Noguera Ribagorzana may be as high as in the Valle de Aran, but it has a very different character, being seasonal and concentrated in downpours. Pont de Suert has half as many rain-days per year (66) as Viella (133) (Gaussen, 1956). Seo de Urgell, at a similar altitude on the Segre, with less annual rainfall, has only 44 rain days. This rainfall pattern persists high into the mountains; Erill-la-Vall, high $(1250 \mathrm{~m}$.) up the Noguera de Tort has only 89 rain days per year.

The Noguera Ribagorzana differs from the Segre-Valira, and, indeed, from the Noguera de Tort, in the widespread occurrence of brown shells, and in the high frequencies of unbanded at nearly all altitudes, and in the trend for frequencies of white lip to decrease with increasing altitude. Similarities with the Segre-Valira can be found only at the extremes of the sampling range. A small zone of high frequencies of pink at the head of the Noguera Ribagorzana corresponds to similar zones in two of the high Andorran valleys, while at the Mediterranean ends of both systems there is a predominance of yellows, unbanded and banded shells with extensive banding reductions. The frequency of white lip in these low populations is much higher in the Noguera Ribagorzana than in the Segre.

Trans-watershed comparisons between the two Noguera valleys and the Jueu valley do not reveal important consistencies, even when differences in the altitudinal ranges of vegetation zones are considered. In the Submontane/Montane transition zones of the Noguera Ribagorzana and Jueu there are actually opposite trends in colour and banding morph frequencies. Comparison with the Noguera de Tort is less easy, because of the lack of marked trends there, but there are no close similarities with the Jueu. 
Within each valley, therefore, it is possible to find strong circumstantial evidence for the effective operation of climatic selection. When all systems studied are considered together, however, the various trends and variations seen are to some extent mutually contradictory, and do not fall within the scope of a simple climatic interpretation. Accepting that climatic selection is effective, there are two general interpretations of the situation: climatic variables other than those determining plant zonation are varying to produce the observed morph frequencies; different population-groups of $C$. nemoralis, starting with differing gene-pools, have responded to similar selection pressures in different ways.

These two explanations are clearly not mutually exclusive. They resemble explanations put forward to account for Area effects in some English populations of C. nemoralis (Gain and Currey, 1963; Goodhart, 1963; Cain and Currey 1964; Clarke, 1966), and it is, therefore, worth investigating any evidence bearing upon them.

As Arnold (1968) points out, the other valleys on the north side of the watershed surveyed by Lamotte $(1951,1968 a, b)$ show trends in morph frequencies similar to those in the Garonne. Within the Garonne system there is also a high level of consistency between tributaries. It is when the southern side of the Pyrenees is considered that apparent inconsistencies arise. This kind of result might be expected from what is known about the relationships of macro and micro climates. The north side of the Pyrenees is subject to a mild maritime climate, without extremes of temperature, and with cloud and rain at all times of year. The south side, by contrast, is subject to a more Mediterranean regime, with season rainfall, often in deluges, and very high summer temperatures with intense insolation. The latter type of climate causes much greater differences in microclimates between places differing in topography, aspect and plant cover. One might therefore expect less internal consistency on the south side. Arnold (1969) has demonstrated the pronounced effects of changes in topography and habitat on $C$. nemoralis morph frequencies in the lower Segre valley.

As shown above, there are considerable climatic differences between the valleys of the Noguera Ribagorzana and Noguera de Tort on the one hand, and the Segre-Valira system studied by Arnold on the other. Mediterranean influence extends further up in the latter, and even the montane zone is drier, as indicated by the predominance of Pinus forests rather than Fagus/Abies ones (Gaussen, 1956). It is, therefore, not surprising to find considerable differences in morph frequencies between the two areas, even when the same zones are considered.

Conversely, detailed comparisons of morph frequencies in the Noguera de Tort and Noguera Ribagorzana support the conclusion that different populations have responded differently to similar selection pressures. The two valleys have been sampled over a similar range of altitude, through the same geological sequence, occurring at roughly the same altitudes ir each, and from a similar range of habitats. They are adjacent, and have a similar aspect. There is indeed some evidence of differences in climate between the two. Buxus extends further up the Noguera de Tort, suggesting that its head, at least, may be somewhat drier; while Mediterranean plants of various species extend further up the Noguera Ribagorzana. This latter may be due to the greater extent of clearance in the Noguera Ribagorzana, which does not seem to have influenced morph frequencies drastically over the last 
50 years. In general, though, our botanical surveys and detailed site-bysite comparisons show great similarity between the two valleys.

By contrast, morph frequency variations in the two valleys are completely different. No trend in one valley is repeated in the other. Even a linkage disequilibrium is reversed: white lip is in excess in yellow as opposed to pink shells in all but one sample in the Noguera Ribagorzana, the one exception being far from the Noguera de Tort. In the Noguera de Tort, all samples, except the lowest two nearest the junction with the Noguera Ribagorzana, show an excess of white lip in pinks. The two lowest samples of the Noguera de Tort show another sign of "belonging" to the Noguera Ribagorzana series, in that they are the only two samples in the valley to contain brown shells, although many sites of suitable habitat for this morph were sampled higher up.

We tentatively conclude that both explanations above are needed to account for our data. The use of botanical evidence has helped us to detect rather subtle variations in climate, and $C$. nemoralis populations appear to respond to them. There are also substantial differences in both morph frequencies and linkage disequilibria between populations living in apparently similar climates, in areas where climatic selection is effective. This suggests that differences in population histories do affect the present-day situation. It follows that exact correspondence between morph frequencies and such broad climatic indicators as vegetational zonation will not be found on a general basis, even though correspondence in particular areas may be very good. Such lack of consistency is no ground for dismissing climate as an effective agent of selection on Cepaea.

Acknowledgments. - On both visits to the Pyrenees we were helped by many others; in 1966 by Mrs B. Haynes and Dr R. Reay and by many students from Portsmouth Polytechnic, and in 1969 by Mr J. F. Ainsworth, Mrs M. Cameron and Dr D. I. Morgan-Huws. Without their help our task would have been impossible. Dr R. W. Arnold has helped us continually with discussion and advice, and Professor A. J. Cain kindly read a draft of the paper in manuscript. Dr Paul Harvey computed the chromosome frequencies for us. Thanks are due to Miss J. Switzer for facilities provided at Portsmouth Polytechnic.

\section{REFERENGes}

ARNor.D, R. W. 1968. Climatic selection in Cepaea nemoralis $(\mathrm{L})$ in the Pyrenees. Phil. Trans. Roy. Soc. Lond. B, 253, 549-593.

ARNOLD, R. W. 1969. The effects of selection by climate on the land-snail Cepaea nemoralis (L). Evolution, 23, 370-378.

ARNold, R. W. 1971. Cepaea nemoralis on the east Sussex South Downs, and the nature of Area effects. Heredity, 26, 277-298.

atLas de france (no date). Comité Nationale de Geographie; Emm. de Martonne, Secretary General. Paris: Editions Geographiques de France.

baron, z. 1955. Guida Botanica D'Italia, 4th ed. Capelli Editore.

BOFILL, A., AND HAAs, F. 1920. Estudi sobre la malacologia de les valls pirenaiques: Vall del Noguera Ribagorcana. Treballs Mus. Cienc. Natur. Barcelona, 3, 1-99.

BOFIL, A., AND HAAB, F. 1921. Estudi sobre la malacologia de les valls pirenaiques: Vall d'Aran. Treballs Mus. Cienc. Natur. Barcelona, 3, 1247-1350.

воусотт, A. E. 1934. The habitats of land Mollusca in Britain. 7. Ecol., 22, 1-38.

CAIN, A. J., AND GuRReY, J. D. 1963. Area effects in Cepaea. Phil. Trans. Roy. Soc. Lond. B, $246,1-81$.

CAIN, A. J., AND currey, J. D. 1964. The causes of Area effects. Heredity, 18, 467-471.

CAIN, A. J., AND shepPard, P. M. 1954. Natural selection in Cepaea. Genetics, 39, 89-116.

CANN, A. J., sheppard, P. M., AND KNNG, J. M. B. 1968. The genetics of some morphs and varieties of Cepaea nemoralis (L). Phil. Trans. Roy. Soc. Lond. B, 253, 383-396. 
CAmeron, R. A. D. 1969. The distribution and variation of Cepaea nemoralis L. near Slievecarran, County Clare and County Galway, Eire. Proc. malac. Soc. Lond., 38, 439-450.

CARTER, M. A. 1968. Area effects and visual selection in Cepaea nemoralis (L.) and Cepaea hortensis. Phil. Trans. Roy. Soc. Lond. B, 253, 397-446.

GEPPELLINI, R., SINISCALSO, M., AND SMTTH, c. A. B. 1955. The estimation of gene-frequencies in a random mating population. Annals. of Human Genetics, 20, 97-115.

Clarkz, B. c. 1966. The Evolution of morph-ratio clines. Amer. Nat., 100, 389-402.

cook, L. M. 1966. Notes on two colonies of Cepaea nemoralis (L) polymorphic for white lip. 7. Conchol., 26, 125-130.

Coste, н. 1937. Flore descriptive et illustrée de la France. Libraire des Sciences et des Arts, Paris.

CURREY, J. D., ARNOLD, R. W., AND CARTER, M. A. 1964. Further examples of variation of populations of Cepaea nemoralis with habitat. Evolution, 18, 111-117.

ellenberG, H. 1963. Vegetation Mitteleuropas mit den Alpen in Kausaler, dynamischer und historischer Sicht. Ulmer, Stuttgart.

rournier, P. 1961. Les quatre flores de la France. Paul Lechevalier, Paris.

FRöbIN, J. 1927. Contribution à la connaissance de la végétation des Pyrénées centrales Espangnoles. Lunds Universitets Arsskrift, N.F., 23, 1-46.

gaussen, H. 1956. La végétation des Pyrénées espagnoles. Veroff. Geobot. Inst. Rubel. Zurich, 31, 91-123.

Griger, R. 1959. The Climate near the Ground. Mass. Harvard University Press, Cambridge.

COODHART, C. B. 1963. "Area effects" and non-adaptive variation between populations of Cepaea (mollusca). Heredity, 18, 459-465.

GUERRUCCI-HENRION, M. A. 1966. Recherches sur les populations naturelles de Cepaea nemoralis en Bretagne. Arch. Zool. Exp. et Gen., 107, 369-417.

xLeixsmiede, w. r. J. 1960. Geology of the Valle de Aran (Central Pyrenees). Leidse Geol. Med., 25, 131-241.

LAMOTTE, M. 1951. Recherches sur la structure génétique des populations naturelles de Cepaea nemoralis (L). Bull. Biol. (Suppl.), 35, 1-239.

LAMOTTE, M. 1966. Les facteurs de la diversité du polymorphisms dans les populations naturelles des Cepaea nemoralis (L.) Lavori della Societa Malacologica Italiana, 3, 33-73.

LAMOTTE, M. 1968a. Les traits généraux du polymorphisme de la coquille dans les populations naturelles de Cepaea nemoralis (Mollusques, Helicidae) des Pyrénées françaises. C.R. Acad. Sci. Paris, 267, 1318-1321.

LAMOTtE, M. 1968b. Influence de l'altitude sur la fréquence du caractere "absence de bandes" dans les populations de Cepaea nemoralis (Mollusques, Helicidae) des Pyrénées françaises. C.R. Acad. Sci. Paris, 267, 1649-1652.

LUdr, w. voN. 1956. Die Pflanzenwelt Spaniens. Ergebnisse der 10 Internationaler Pflanzengeographischen Exkursion (I.P.E.) durch Spanien 1953. I Tiel. Veroff Geobot. Inst. Rubel. Zurich, 31, 1-297.

MURRAY, J. 1964. Multiple mating and effective population size in Cepaea nemoralis. Evolution, 18, 283-291.

OBERDORFER, E. 1962. Pflanzensoziologische Exkursions flora fur Suddeutschland und die angrenzenchen Gelrete Verlag Eugen, Ulmer.

PERROT, J. L., AND PERROT, M. 1938. Monographic des Helix du groupe Cepaea; contribution à la notion d'espèce. Bull. Biol., 72, 232-262.

RIJCKBORst, r. 1967. Hydrology of the upper Garonne basin (Valle de Aran, Spain). Leidse. Geol. Med., 40, 1-74.

RIVAS-GODOY, J. 8. 1956. Ubersicht uber die Vegetationsgurtel der Iberischen Halbinsel Kennzeichnende Arten und Gessellschafter. Verof. Geobot. Inst. Rubel. Zurich, 31, 32-69.

SAPPA, D. P. 1956. Sulla posizione des Quercetum lusitanicae nella vegetazione forestale Spagnola. Veroff. Geobot. Inst. Rubel. Zurich, 31, 164-176.

schmid, E. 1956. Du Vegetationsgurtel der Iberisch-Berberische Gurtel. Veroff. Geobot. Inst. Rubel. Zurich, 31, 124-163.

tUXEN, R., AND OBERDORFER, E. 1958. Die Pflanzenwelt Spaniens. II Tiel: Eurosibirsche Phanerogamen-Gessellschafter Spaniens. Veroff. Geobot. Inst. Rubel. Zurich, 32, 1-321. WOLDA, H. 1967. The effect of temperature on reproduction in some morphs of the landsnail Cepaea nemoralis (L). Evolution, 21, 117-129. 


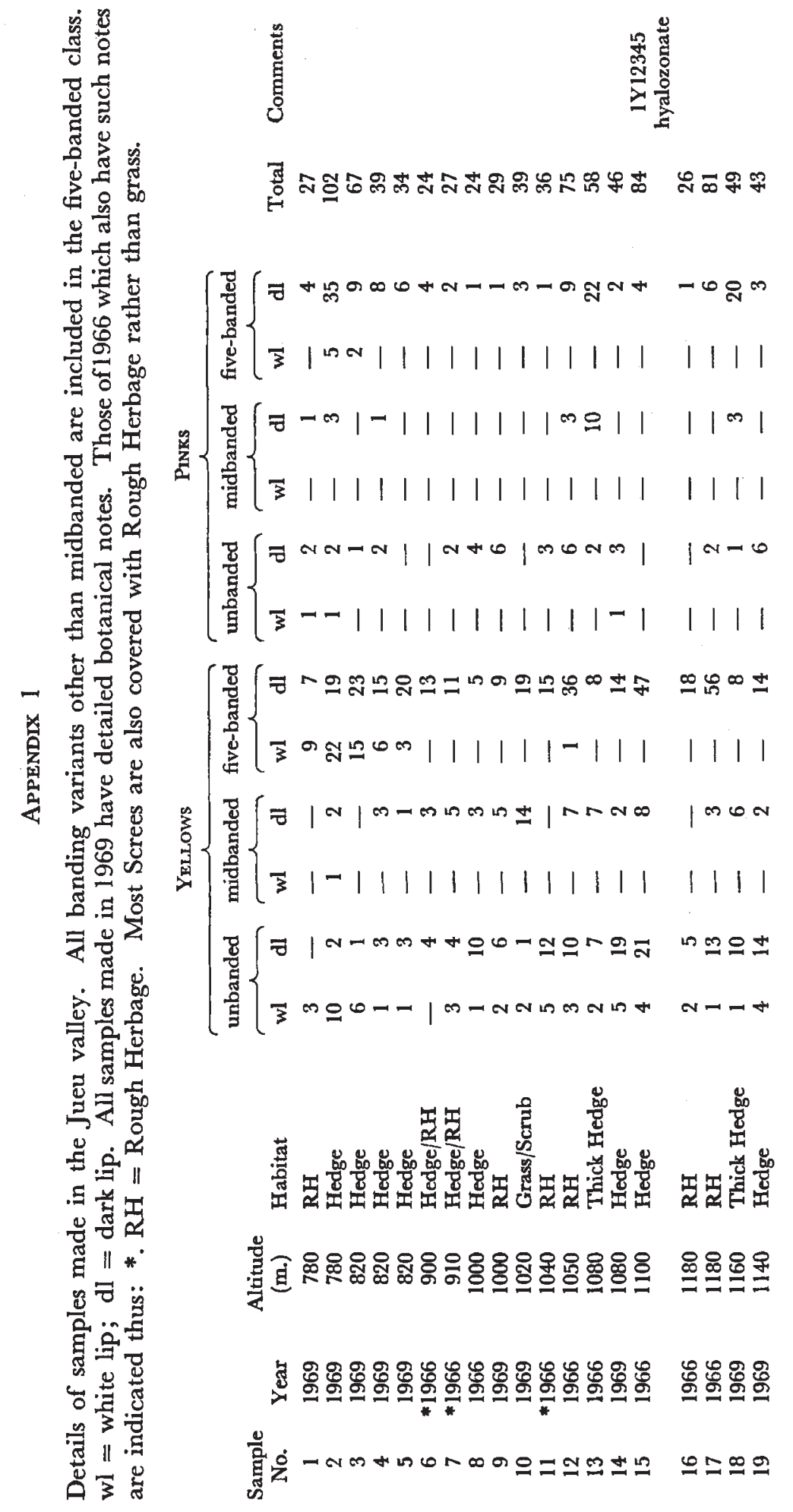


है

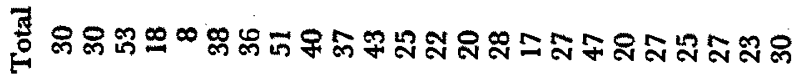

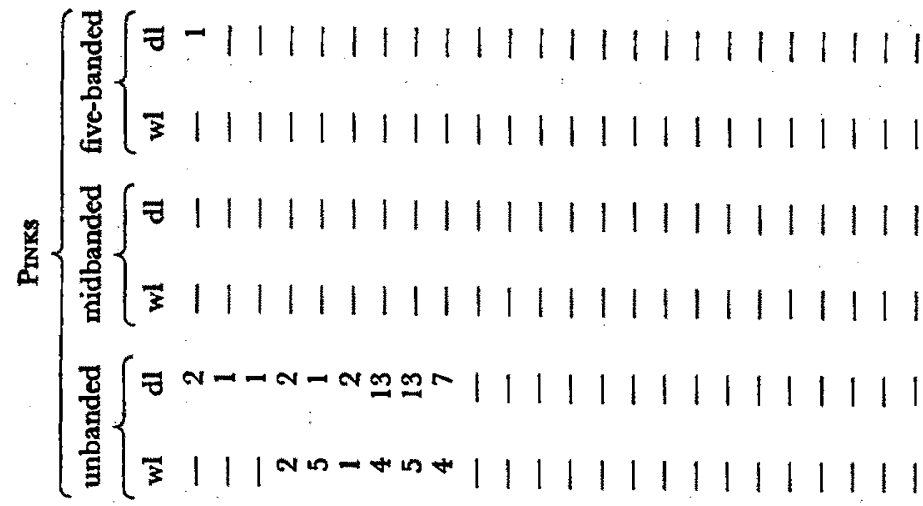

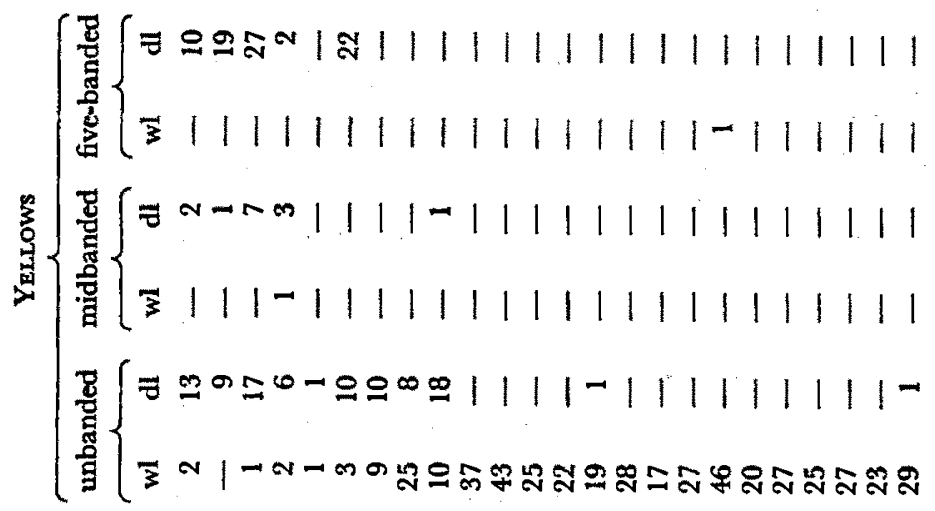

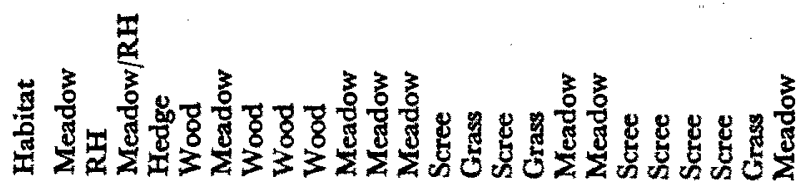

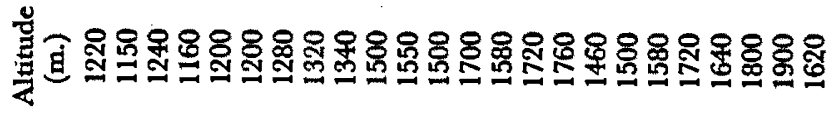

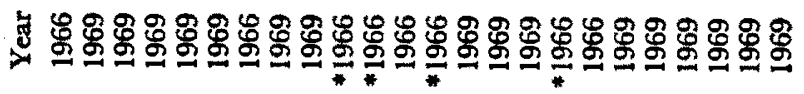

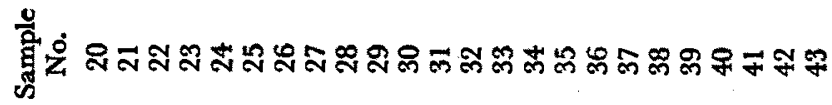


R. A. D. CAMERON, M. A. CARTER AND F. N. HAYNES

芩

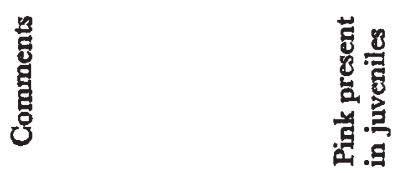

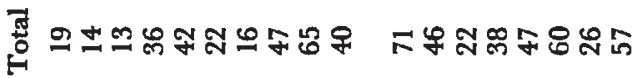

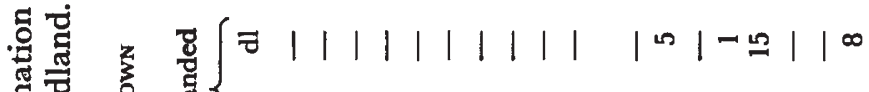

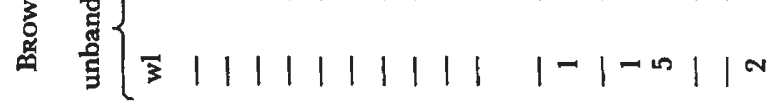
象

a d

范

还宽

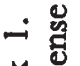

\&

过

ㅇ.?

品

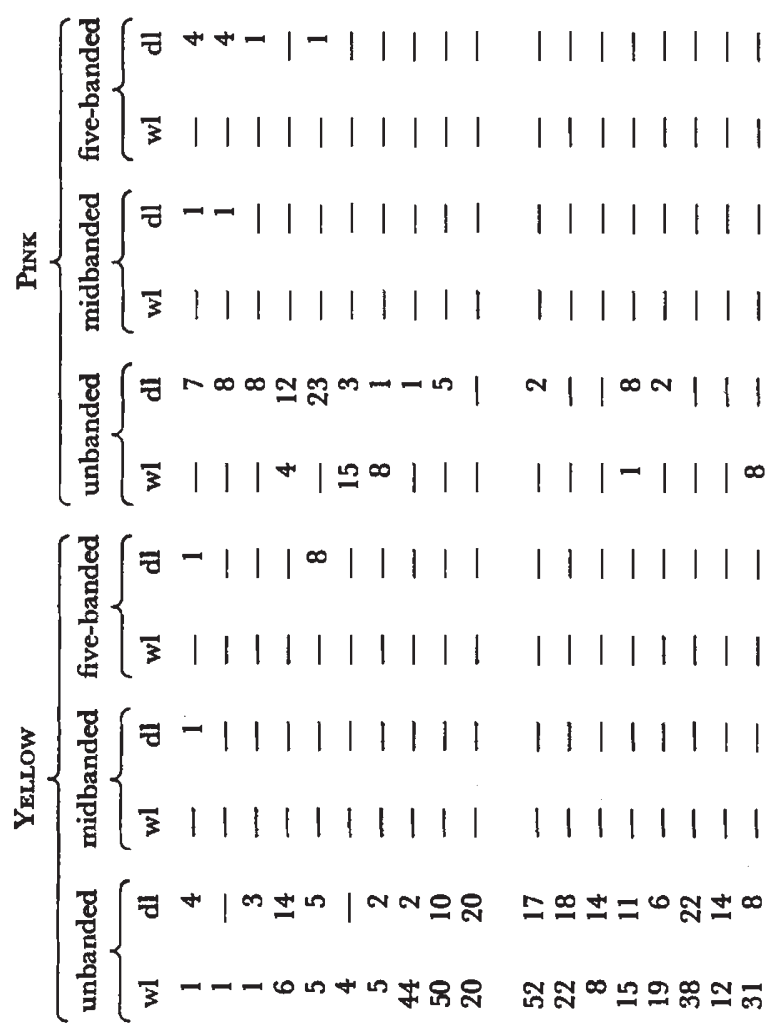

乙.

द्ञा

.

己ृ

สุ

월

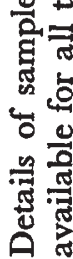

荧

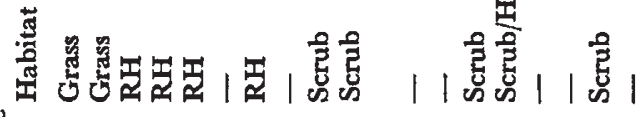

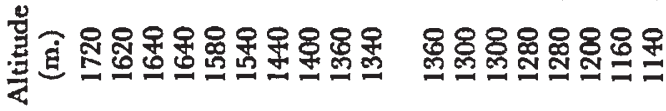
茫

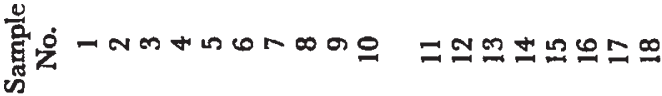




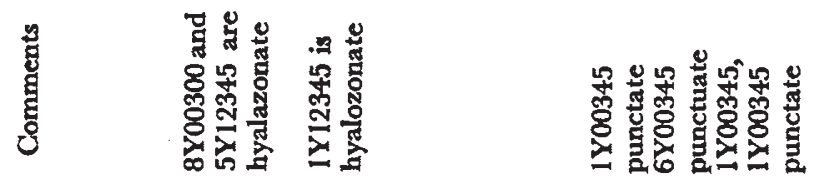

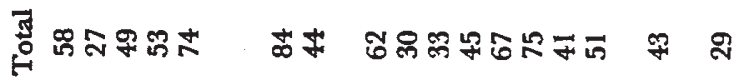

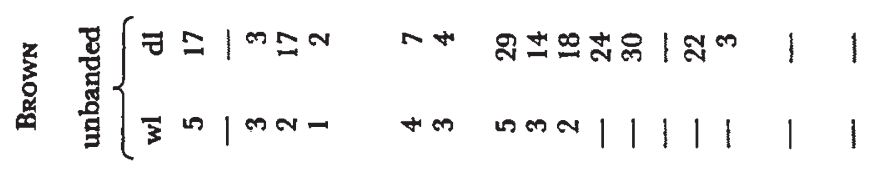

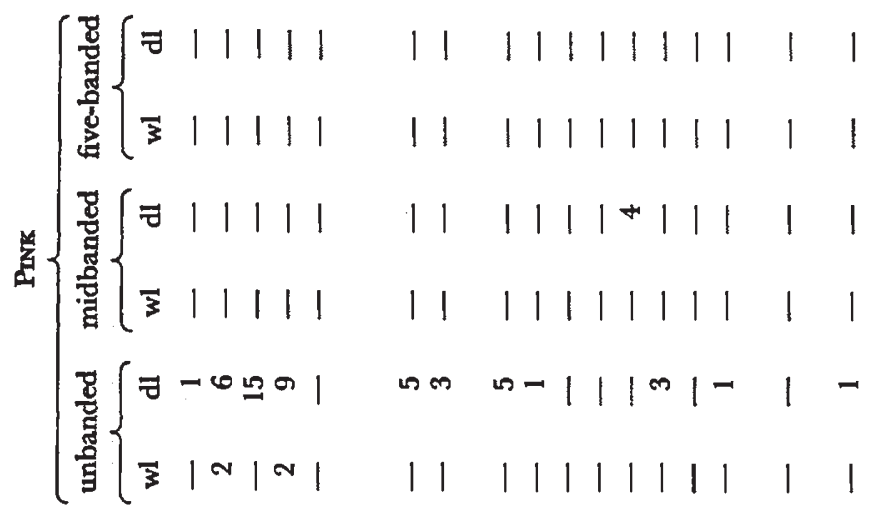

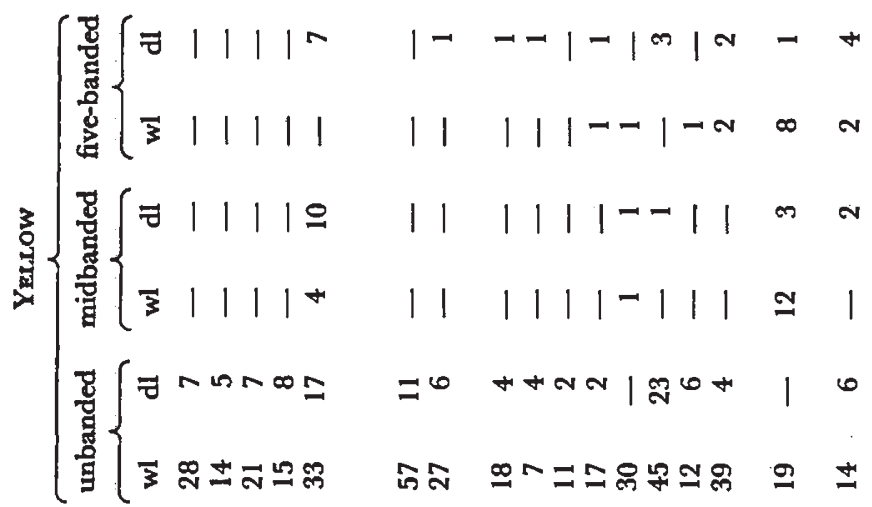

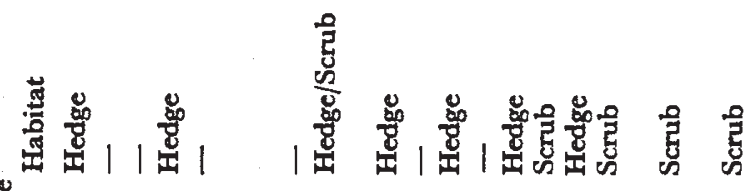

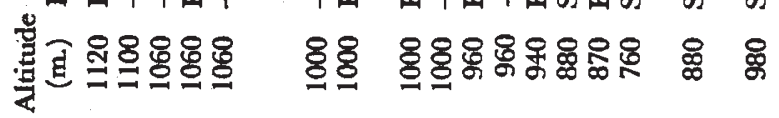

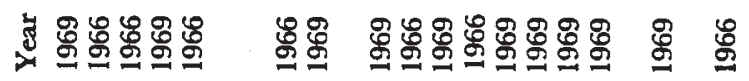

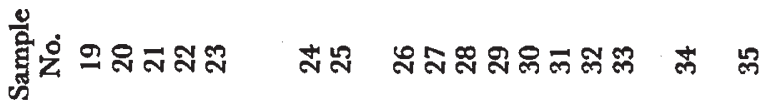


R. A. D. CAMERON, M. A: CARTER AND F. N. HAYNES

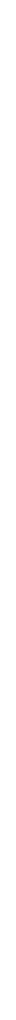

苍葋

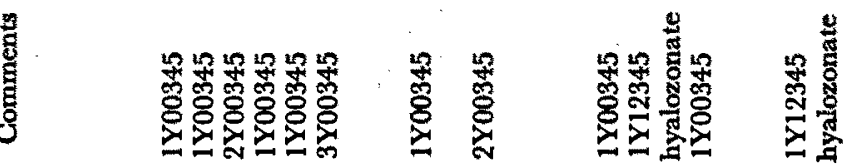

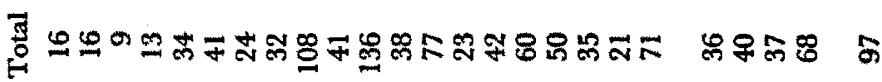

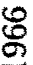

这豈

की

.

吾

$\because \frac{1}{4}$

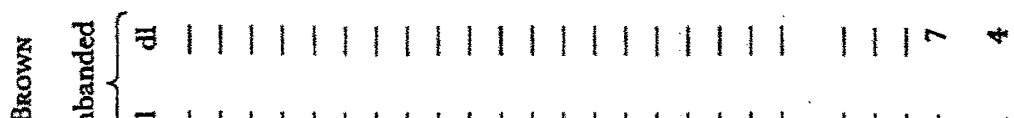
3

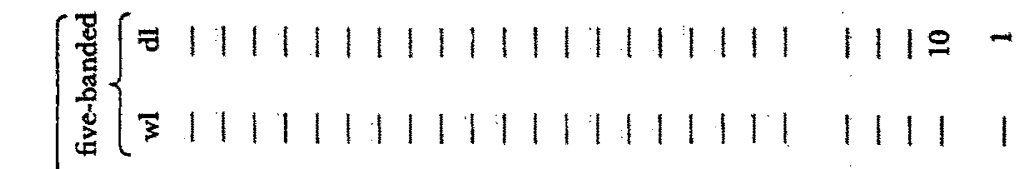

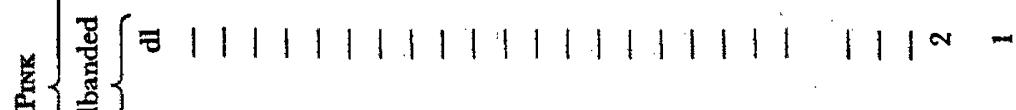
31111111111111111111111111 总 $\{11111111111111111111,1110 \mathrm{~N}$

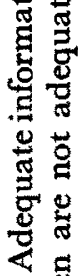
$\dot{x}$ गे 능 E ชั 행

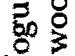

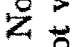
을 \&.

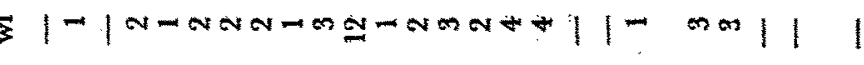

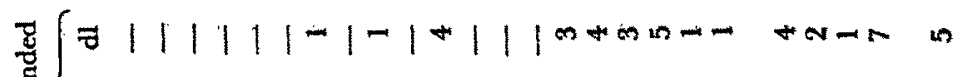

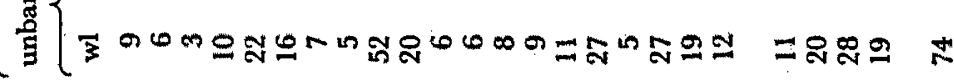
을 焉营

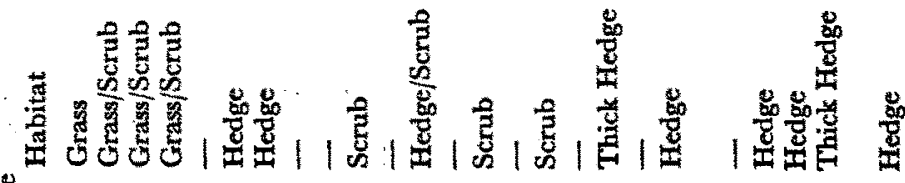

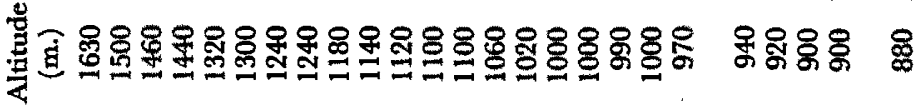
ఫ

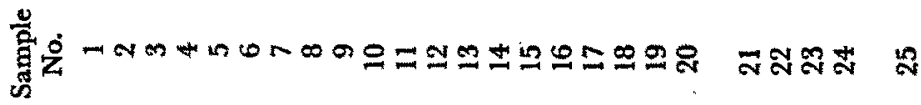

